\title{
Particles in Slow Motion
}

\author{
IBY J. S. McNOWN \\ ASSOCIATE DIRECLOR, INSTITUTE OF HYIRAULIC RESEAIRCH, IOWA CITY \\ FUIBHIGHT RESEARCH SCHOLAR, NEYRPIG HYDHAUTAC IABORATORY, GRENOBLE
}

Texte français, p. 711 .

NOMENCLATURE

a Semi-axis of ellipsoid oriented parallel to the direction of motion.

$b, c$ Semi-axes of ellipsoid normal to the direction of motion $(b \geqslant c)$.

a Diameter of spherical particle.

d $l^{\prime}$ Diameter of circular disk.

J) Diameter of cylindrical container.

IF External force acting on particle.

k. Coefficient.

K Resistance coefficient ( $\mathrm{F} / 3 \pi \mu \mathrm{V} d$ ).

I. Distance between two parallel plane boundaries.

$(\Omega$ Reynolds number of particle $(\mathrm{Vd} / \mathrm{y})$.

$R^{\prime}$ Reynolds number of fluid (VD/y or $\left.\mathrm{Vs} / \mathrm{v}\right)$. $s$ Distance between centers of two particles. Distance between center of particle and plane boundary.

$\checkmark$ Velocity of particle.

$\varepsilon$ Coefficient of surface viscosity.

$\theta$ Angle between the vertical and the line of centers for two spheres.

3. Dynamic viscosity of fluid medium.

$u^{\prime}$ Dynamic viscosity of fluid particle.

$\checkmark$ Kinematic viscosity of fluid medium (u. $/$ ?).

Density of the fluid medium.

$\rho^{\prime}$ Density of the particle.

$\varphi$ Angle of inclination beiween the vertical and the plane of a disk.

\section{INTRODUCTION}

Just a century ago Stokes presented the scientific world with his theory of the "internal friction of fluids ${ }^{1}\left({ }^{*}\right)$, which has since found applications in many investigations. Perhaps the best known result from this study is the simple equation for the motion of a sphere ${ }^{2}$, which is appropriately called the Stokes Law. The derivation was restricted to solid spherical particles moving very slowly in a fluid both homogeneous and infinite in extent. The importance of the several restrictions has been studicd by others, and, as a consequence, the effects resulting from velocities beyond "the

$\left.{ }^{\star}\right)$ Superseripts refer to the list of references at the end (p. 719).
Stokes range" $\left({ }^{* *}\right)$, the presence of finite boundaries, other shapes than the spherical, and particle fluidity, have been evaluated. Analyses and summaries of the movement of particles at small Reynolds number's have been presented by Smoluchowski ${ }^{3}$, Oseen ${ }^{4}$, Weyssenhoff 5 , Schiller ${ }^{6}$, and Lamb 7 , among others, but with the presentation of various more recent investigations, some hitherto unpublished, these treatments are no longer sufficient.

The most significant results can conveniently

(" ") For simplicity of expression " the Stokes range" will be used hereafter to designate those conditions for: which Stokes methods of analysis are applicable, i.c. those for which accelerations can be neglected without introducing significant errors. 
be based on a slightly modified form of the Stokes Law $\left(^{* * *}\right)$;

$$
\mathbf{F}=(3 \pi v V d) \mathrm{K}
$$

the factor $K$ being inserted in the otherwise familiar equation; is is the viseosity of the fluid, $V$ the constant velocity of the sphere, $d$ its diameter, and $F$ the external force producing the motion (usually the buoyant weight of the sphere). The dimensionless quantity $K$, which is the ratio of the external force to the viscous force, can appropriately be designated as a Stokes number; in this definition the numerical value has been so chosen that $K=1$ for a motion which meets the various conditions imposed by Stokes. From another point of view, $\mathrm{K}$ is a function of one or more of the various quantities which cause departures from the Stokes law, such as the inertia effects (if not small), the extent of the fluid, the shape of the particle, and event the fluidity of the particle as for drops or bubbles.

For motion at small Reynolds numbers ${ }^{\star \star \star \star *}$ ), the parameter $\mathrm{K}$ is preferable to the conventional coefficient of drag because the actual resistance varies little with the Reynolds number. If accelerations are negligible, there is little ulility in a functional relationship which, in eflect, depends upon their relative magnitude. Thus, $K=1$ is a more precise characterization of the motion of a sphere in accordance with the assumptions of Stokes than is $C_{D}=24 / \mathcal{R}$. In a wholly analogous manner one could define a Poiseuille number, which is a constant for laminar flow in a circular tube, in preference to a resistance coefficient which varies artificially with the Reynolds number. Because of its greater significance and utility, $K$ will be used in the ensuing discussion of the various modifications of the Stokes Law.

To be sure, $\mathrm{K}$ varies significantly with $R$ if the latter excecds approximately 0.1 ; this variation is the best known of the several already mentioned. The works of Oseen and Goldsteins and numerous experimental results are so well documented in reference works 5,9 that they will not be reviewed in detail here.
But even for the study of this effect, insofar as we are interested in departures from the Stokes law for comparatively low Reynolds numbers, the parameter $\mathrm{K}$ appears to be preferable to the drag coefficient. 'That is, Oseen's result, which indicates the significance of inertia effects for values of $R$ below unity, is expressed simply as

$$
\mathrm{K}=1+\frac{3}{16} \Re
$$

Both theoretical and experimental studies have been conducted for the determination of many other effects. The results of the experiments have served to define the region of applicability of the theory, to determine oceurrences beyond these limits, and to provide information for cases in which the boundary conditions are not readily adaptable to theoretical calculation.

The applications of these and related studics appear to be limitless. In the natural sciences the geologist, the oceanographer, the physicist, and the meteorologist all have an active interest in the problem. And in the applied sciences the hydraulic engineer shares his interest with the metallurgist, the chemical engineer, and others. Even in the biological sciences, the fall relocity is important in studics of blood and other suspensions. For such a broad field, no treatment could be complete cven from the stand-point of bibliography, and the following discussion is limited to some of the more significant cases on which our knowledge is reasonably well defined. In addition to a summary of the pertinent works which have been published already, the results of new computations and experiments on the effects of orientation and certain boundary conditions are presented.

This study was begun at the Iowa Institute of Hydraulic Research and completed at the Neyxpic Hydraulic Laboratory. The author was materially assisted by members of the Neyrpic staft in the search for and the procurement of the necessary references, in the preparation of the figures and Appendices, and in the translation of the text.

\section{EXTENT OF THE FLUID}

As the imfinite fluid assumed by Stokes is a practical impossibility, much study has been

$\left({ }^{* *}\right)$ The equations presented in this discussion and other equations related to the subject are given in the Appendix.

$\left({ }^{* * *}\right)$ Calculation of the Reynolds number throughout this discussion is based on the diameter of the sphere $(R=V d / v)$. devoted to the effect of the boundary of the fluid. Theories have been devised and numerous experiments have been conducted in evaluating the necessary modifications if a particle falls in the vicinity of fixed boundaries or near other particles. From the results of these studies, one can evaluate the magnitude of the correction for several comparatively simple cases. 


\section{CyLANDRICAL BOUNDARY}

The most common problem is the determination of the effect of a cylindrical container with the sphere falling along the axis of symmetry, a condition occurring in viscosity determinations, in demonstrations of free fall, and in various laboratory investigations. rithe theories and experiments for the resolution of this problem are numerous, dating from the classic investigattions of Allen in $1900^{10}$, and those of Arnold ${ }^{11}$, Ladenburg ${ }^{12}$, Cunningham ${ }^{13}$ and Smoluchorski a decade later. Since then, many studies have been made, and summaries have been presented by Schiller and Merrington ${ }^{14}$. In a recent study at the Iowa Institute of Hydraulic Research a the scope of investigation was extended to the limit for which the diameter of the splhere is nearly equal to the diameter of the cylindrical container.

In a theoretical study, Ladenburg, utilizing a method presented by Lorentz ${ }^{16}$, derived an approximate expression for the efrect of a cylindrical boundary. Faxén ${ }^{17}$ introduced corrections of a higher order in the effect of $d / \mathrm{D}$ (the ratio of the diameters of the sphere and the cylinder), and exlended the study along the same line of attack used by Oseen to include small acceleralive effects. For very small Reynolds numbers, and for small values of $d / D$, Faxén's result (see Appendix) reduces to:

$$
K=1+2.1 \frac{d}{D}
$$

He pointed out that the coefficient 2.4 obtained by Ladenburg differed from his result of 2.1 because of an error in the former's calculation.

An interesting comparison can be made be- tween the results for the cylindrical and the spherical containers, the particle moving in the latter case at the center of the sphere at the moment considered. Allhough the spherical boundary itself holds only academic interest, the fact that it closely resembles the cylindrical boundary in the region of maximum importance makes its calculation by Cunningham pertinent. The exact expression obtained for the comparalively simple boundary condition of the concentric sphere, is presented in the Appendix; to a second approximation this result becomes:

$$
\mathrm{K}=1+\frac{9}{4} \frac{d}{\mathrm{D}}+\left(\frac{9}{4} \frac{d}{\mathrm{D}}\right)^{2}
$$

It is evident that the resistance for a spherical boundary should exceed that for a cylindrical one, and the result of Ladenburg is thus undoubtedly too high, whereas that of Faxén is qualitatively substantiated.

An approximate theory was given by McNown et al ${ }^{15}$ for the motion of a sphere within a cylindrical boundary with the diameter of the sphere nearly equal to that of the cylinder. The assumption is made that the flow between the sphere and the cylinder is slowly varied and two-dimensional, and that the resistance is important only within a small region near the equator of the sphere. The calculation resulted in the following equation:

$$
\mathrm{K}=1.66\left(1-\frac{d}{\mathrm{D}}\right)^{-. / / 2}
$$

This simplified analysis can be modified to include the case in which the sphere moves, not along the axis, but eccentrically with a rolling contact at the cylinder wall. The space between

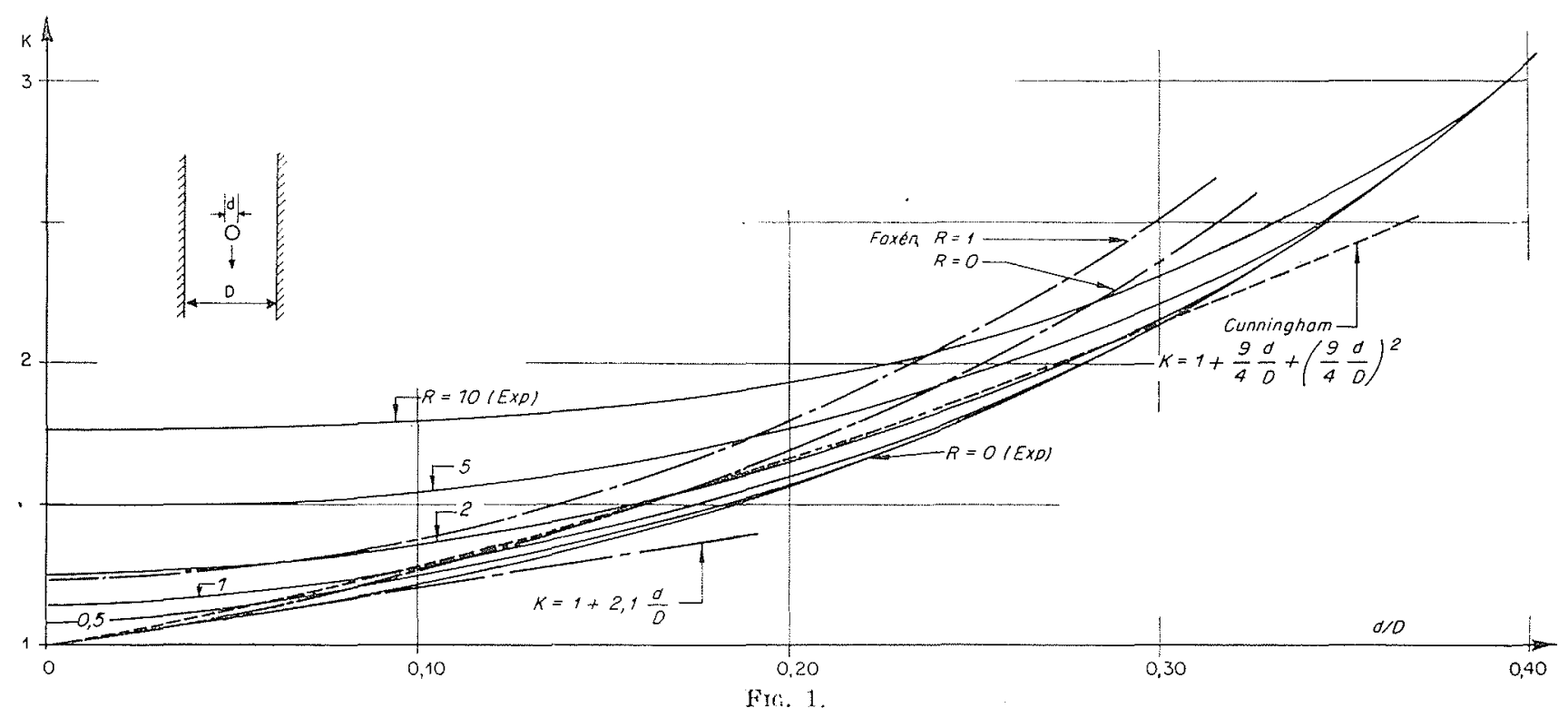


the cylinder and the sphere at the equator is assumed to vary from zero to $\mathrm{D}-d$ in accordance with the expression $(\mathrm{D}-d)(1+\cos 0) / 2$ in which 0 is measured in the plane of the equator. The corresponding value of $K$ is:

$$
\mathrm{K}=0.868\left(1-\frac{d}{\mathrm{D}}\right)^{-5 / 2}
$$

the resistance being about half of that for the preceding case.

The various experiments which have been made with a sphere settling in a vertical cylindrical container make possible a comparison and evaluation of the several theories. Curves obtained from experiment are compared with the theoretical curves in Fig. 1 for diameter ratios from 0 to 0.4 . The linear approximation is readily seen to have a very limited applicability, whereas the higher order approximations are fairly close to the linniting experimental curve (for small values of $(R$ ) throughout most of the indicated range of $d / D$. Curves for $R=$ con-

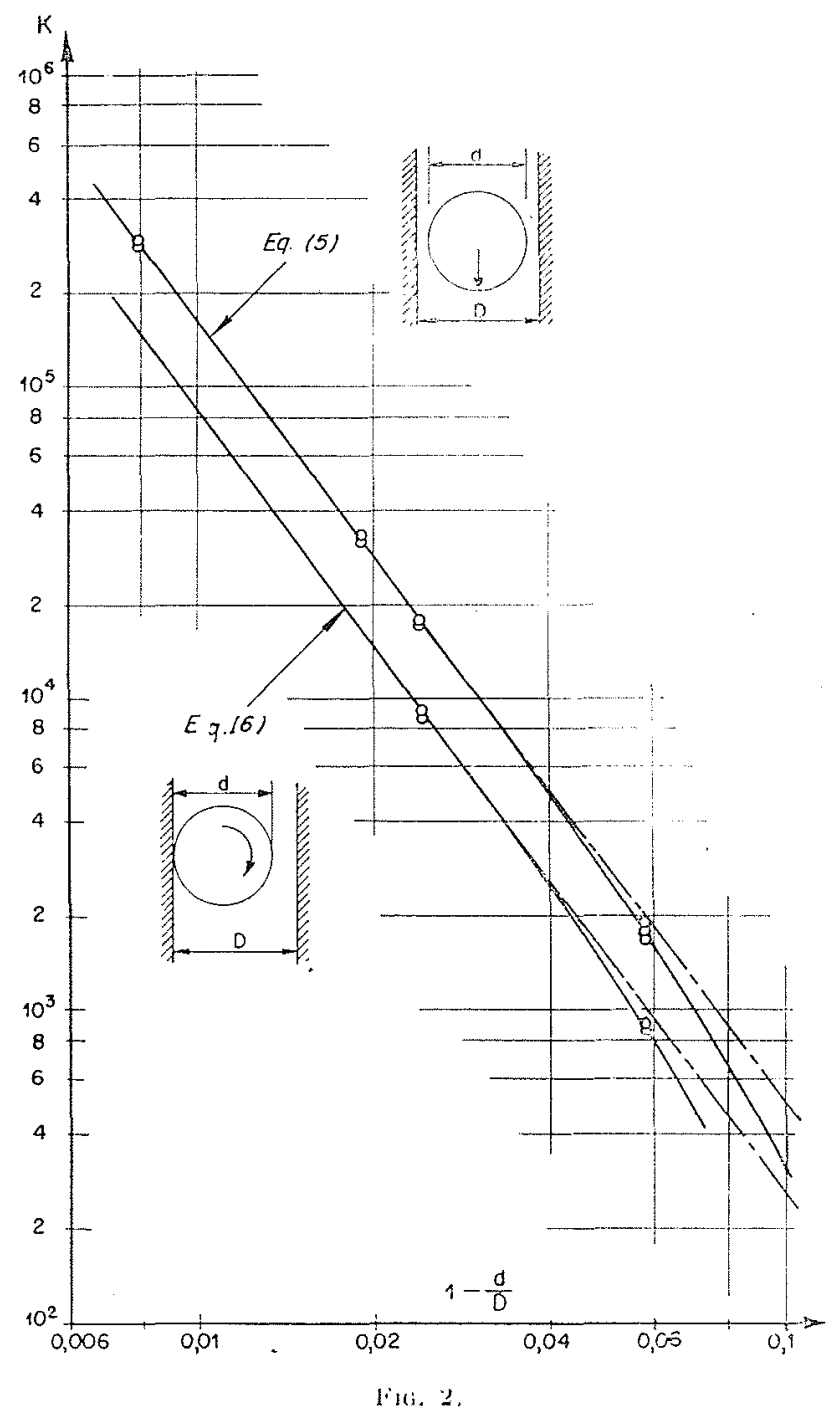

stant have been interpolated from the experimental results (principally those obtained at Iowa ${ }^{15}$ ). It is noteworthy that for increasing values of d/D, these curves approach the limiting curve corresponding to motion with negligible accelerations. That is, the value of $\mathcal{R}$ designating the upper limit of the Stokes range increases with increasing $d / D$. Faxén's modification for accelerative effects is illustrated by the inclusion of a computed curve for $\Omega=1$. The decrease in the magnitude of these effects with increasing $d / \mathrm{D}$, found experimentally, is less marked in the theoretical result; the modification is thus seen to be too large.

In the study at the Iowa Institute of Hydraulic Research, the results were also obtained for $d / D$ nearly equal to unity, as shown in Fig. 2. For values of $d / D$ greater than 0.95 the plot of the experimental results was found to coincide with that of Eq. (5), provided that the tube was truly vertical and the Reynolds number very low (less than 0.001). If either of these conditions was not fulfilled, the sphere tended to move asymmetrically, rolling as it fell. The resistance then corresponded closely to that obtained from Eq. (6), as also shown in Fig. 2.

\section{VERTICAL PLANE BOUNDARIES}

The slow motions of a spherical particle in the vicinity of a single vertical wall and between two vertical walls have been studied by Lorentz ${ }^{16}$ and Faxén ${ }^{18}$, respectively. For a single plate the result can be expressed in the form:

$$
\mathrm{K}=1+\frac{9}{32} \frac{d}{s}
$$

in which $s$ is the distance from the center of the sphere to the plane. Oseen ${ }^{t}$ derived an equation which includes terms of a higher order in $d / D$ and also indicated the magnitude of small inertia effects through terms dependent on the quantity Vs/\%. For this motion he obtained a horizontal component which is also dependent upon the latter quantity.

For a spherical particle falling between two parallel plates Faxen's expression, approximate to the first order, is as follows:

$$
\mathrm{K}=1+\frac{d}{\mathrm{I}}
$$

in which $\mathrm{L}$ is the distance between the plates. He also computed a modified form of this motion in which the particle is a distance $\mathrm{L} / 4$ from one of the plates (see Appendix).

\section{HORIZONTAL PLANY BOUNDARY}

The unsteady motion of a freely falling sphere as it approaches a horizontal plate was studied 
by Lorentz. His calculations, in which accelerative effects were neglected even though the velocity of the sphere changes, led to the result,

$$
K=1+\frac{9}{16} \frac{d}{s}
$$

in which $s$ is again the distance from the center of the sphere to the plane boundary. Experimental results presented by Altrichter and Lustig ${ }^{19}$ indicate reasonably good correspondance between theory and experiment if $s / d$ is greater than approximately 15 . For lower values of $s / d$, the effect found experimentally is considerably greater than that indicated from Eq. (9).

\section{TwO OR MORE SPHERES}

If a sphere falls in a fluid medium in which there are other falling spheres, a mutual interaction is found. As each sphere tends to move fluid with it, the velocity of each is increased by the motion of the others if the extent of the fiuid is effectively infinite. In a restricted fluid medium there is, however, a compensating upward flow such that the discharge across any horizontal plane is zero. Near the sphere, in this case, the induced velocily is downward, while some distance away it is upward, and the velocity of a neighboring particle may thus be either increased or decreased, Hence, one can explain the conflicting conclusions reached by Sudry ${ }^{2}$ and Ghali 21 for this kind of motion. For a number of particles more or less uniformly spaced throughout the fluid the net effect would be a reduction in the mean velocity or an increase in the value of $K$.

Smoluchowski calculated the forces acting upon each of two identical spheres in an infinite fluid medium. By means of a superposition of the two sets of forces resulting from considering each sphere fixed and the other moving, he obtained two force components to be combined with the Stokes resistance. One acts in the vertical direction, and is equal to

$$
3 \pi \mathrm{V} d\left[\frac{3}{8} \frac{d}{s}\left(1-\frac{3}{8} \frac{d}{s}\right)\right]
$$

The other acts along the connecting line and in the direction toward the sphere in advance, and is equal to

$$
3 \pi u \mathrm{~V} d\left[\frac{3}{8} \frac{d}{s}\left(1-\frac{9}{8} \frac{d}{s}\right)\right] \cos \theta
$$

in which $\theta$ is the angle between the line joining the centers and the vertical. If the two spheres are in the same horizontal plane the second component is zero, and the corresponding result can be expressed as follows :

$$
\mathrm{K}=1-\frac{3}{8} \frac{d}{s}+\left(\frac{3}{8} \frac{d}{s}\right)^{2}
$$

For two equal spheres following the same vertical path, the two forces are colinear and the result is

$$
\mathrm{K}=1-\frac{3}{4} \frac{d}{s}+\left(\frac{3}{4} \frac{d}{s}\right)^{2}
$$

Equation (11) is also a special case of Faxen's result for two non-equal particles, and that of Dahl (see Faxen ${ }^{2}$ ), these calculations having been carried to higher degrees of accuracy. In still another calculation by Stimson and Jeffery similar values are found for $K$ provided that the distance between the spheres is more than three times the diameter. It should be noted in this connection that the assumptions made in the derivations of equations (7) to (11) are not valid if the spacing is less than a few diameters.

In Fig. 3, the results of theoretical calculations are compared with those obtained experimentally by Bammi $2 t$ for two spheres and for one sphere near a vertical plate. The rather wide divergence between the results is at least in part caused by the presence of the container wall and bottom. Bammi found for two particles that the return flow of the fluid could result in values of $K$ definitely greater than 1 in contrast to Smoluchowski's theoretical result for an infinite fluid. In a few isolated experiments Ghali also found values of $\mathrm{K}$ both greater and less than unity for a pair of spheres.

The foregoing considerations are directly applicable to clouds of spheres. For an isolated cloud, the velocity of each particle would be increased, whereas the descent of particles more or less uniformly distributed throughout the fluid would be retarded. The latter type of motion is approached in studies of sediment and has formed the basis of calculations by Cunningham, Smoluchowsli, McNown et al, and Burgers ${ }^{25}$. The results can be conveniently expressed in the form:

$$
\mathrm{K}=1+k \frac{d}{s}
$$

in which $s$ is an average spacing and $k$ is a constant coefficient which depends upon the various simplifying assumptions made in the calculations. Values of $k$ ranging from 0.7 to 2.2 were obtained by the various investigators. From these calculations it is possible to estimate the effect of sediment concentration on the fall velocity. However, particles of a given size and a uniform spacing were assumed; the effects of a random distribution and of the presence of particles of various sizes remain to be determined experimentally. 


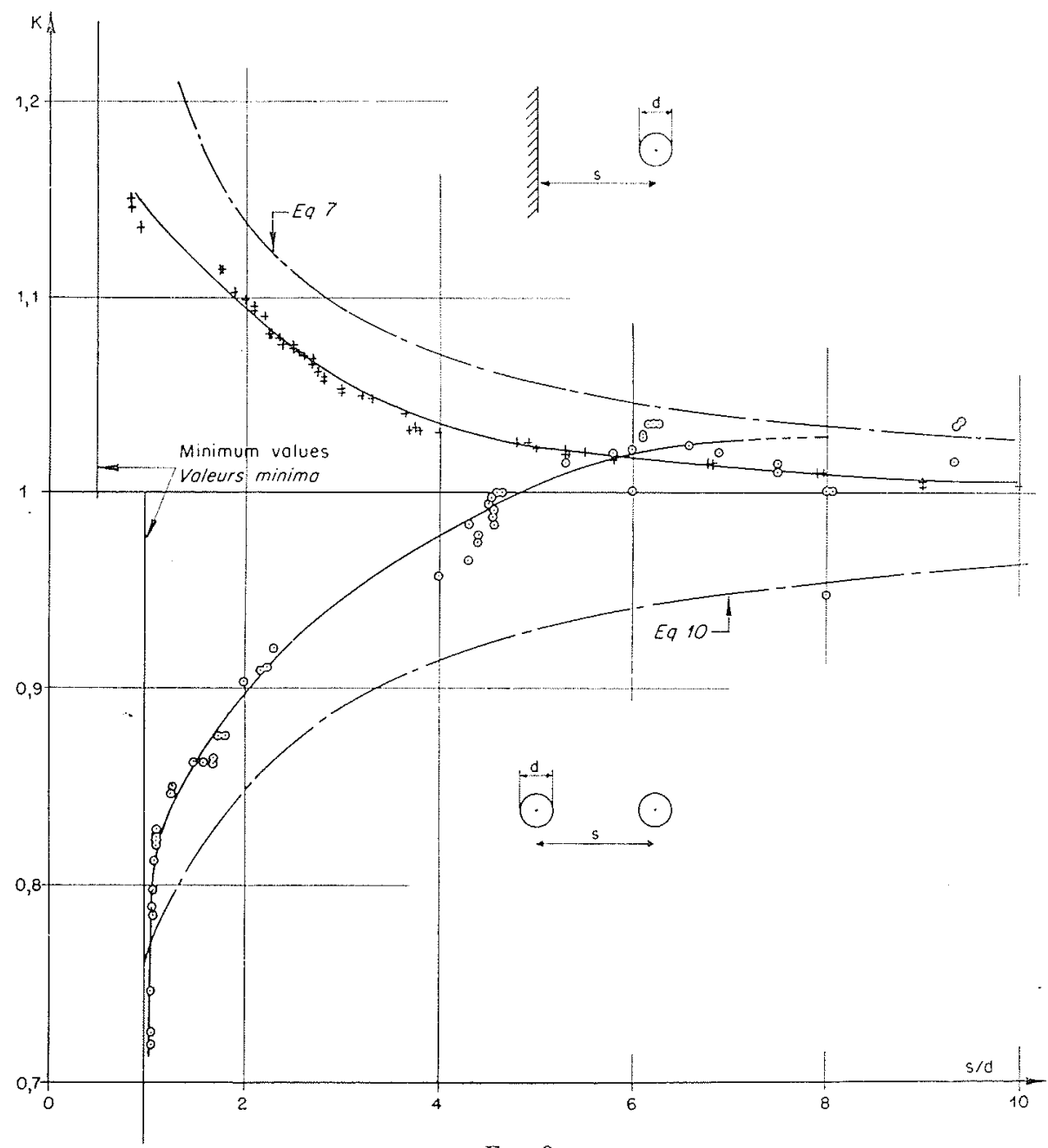

FiG. 3.

\section{PARTICLE SHAPE}

Although the spherical shape is by for the simplest to study either by analysis or by experiment, in many cases information is required for other shapes. As a result, cxtensive investigations of shape efrects have been conducted, particularly in hydraulic engincering, geology, the physics of very small particles, and the manufacture of concrete aggregate. Many complications are encountered in such studies because orientation becomes significant for shapes other than the spherical, and because no single length parameter is sufficient for the definition of the particle form. The ellipsoidal and the cylindrical shapes have been studied analytically, and a wide variety of shapes have been investigated experimentally, including both idealized geometrical forms and natural shapes like those of sand grains.

\section{Ellipsoms}

The fundamental equations for the slow motion of ellipsoidal particles were given by Ober- beck ${ }^{*} 6$ in 1876 , and are summarized by Osecn * and Lamb ${ }^{\top}$. 'These equations lead to elliptic integrals in their craluation, and until a recent publication by McNown and Malaika ${ }^{27}$, the resistance had been determined only for the special cases of the disk and the spheroid 28 . In this publication ${ }^{2-}$, equations and curves were given for the evaluation of the resistance encountered by an ellipsoid moving in the direction of any one of the three principal axes. These results are summarized graphically in Fig. 4, the semiaxis a being taken parallel to the direction of motion, and $b$ and $c$ being so assigned that $b \geqslant c$. The value of $K$ can be defined in the equation:

$$
K=\frac{16}{3 d \zeta}
$$

in which $d$ is the diameter of a sphere with the same volume,

$$
d=2 \sqrt[3]{a b c}
$$


and $\zeta$ is, in general, expressible in terms of elliptic functions.

In all, there are eight different cases, as indicated in Fig. 4, the reduced equations for $\zeta$ being different for each case (see Appendix); the entire possible field is divided into $(a)$ a single

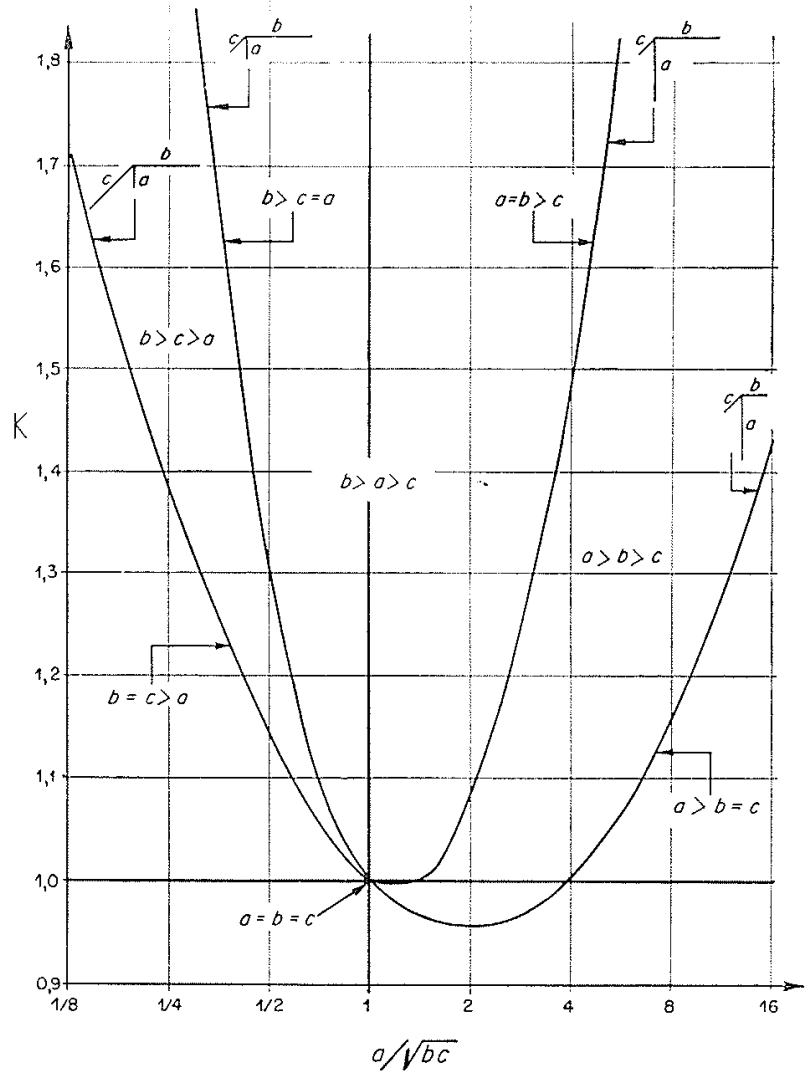

Fic. 4.

point for the sphere, (b) four curve segments for spheroids, and $(c)$ three regions for general ellipsoids. An interesting result of the computation is the delineation of an ellipsoidal shape of minimum resistance for a given volume, which is not spherical but spheroildal with the long axis in the direction of motion and nearly twice the length of the other two. The corresponding minimum value of $K$ is 0.955 . As the axis ratio $a / \sqrt{D C}$ becomes either very small for disk-like particles or very large for rod-like particles, the value of $K$ becomes very large approaching infinity as a limit.

\section{Disks}

The motion of a circular disk, a limiting case of the ellipsoids, has also been studied both theoretically and experimentally. As one of the three principal axes approaches zero in this case, the diameter of the equivalent sphere of equal volume also approaches zero and $K$ approaches infinity (a logical result of the fact that the terminal velocity of such a particle in free fall would be zero). For the sake of comparison, therefore, it is desirable to utilize the diameter of the circle as the reference length, or, in the more general case of the elliptical disk, the diameter of the circle of the same area. Designating this length as $d^{\prime}$ and the corresponding parameter as $K^{\prime}$, one can write:

$$
K^{\prime}=\frac{16}{3 d^{\prime} \zeta}
$$

The variation of $K^{\prime}$ with the ratio of the two non-zero axes is shown in Fig. 5 for the three principal cases of motion : (a) normal to the plane of the disk, $(b)$ in the direction of the major axis, and (c) in the direction of the minor axis. 'The limiting values of $\mathrm{K}^{\prime}$ for the circular

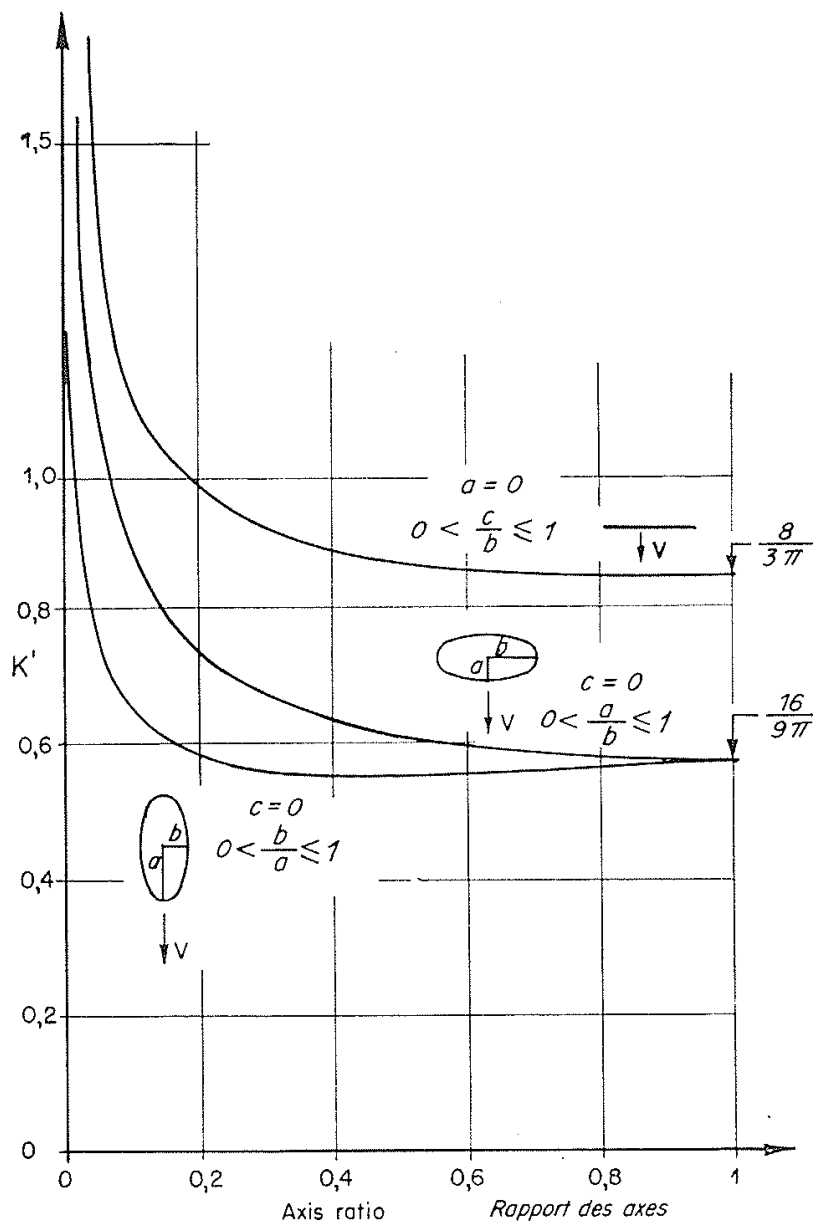
FIG. 5.

disk are $8 /(3 \pi)$ for the first case, and $16 /(9 \pi)$ for the other two. Once again, the minimum value of the resistance coefficient occurs for the case of motion along a major axis approximately twice as long as the minor. 
For Reynolds numbers (based on $d^{\prime}$ ) which are greater than approximately 0.1 the results for the disk differ from those for the modified Stokes Law in much the same way as do those for the sphere. This occurrence was also studied by Oseen ", and he gave the theoretical result

$$
K^{\prime}=\frac{8}{3 \pi}\left(1+\frac{R^{\prime}}{2 \pi}\right)
$$

for the circular disk moving in a direction normal to its plane. The experiments of Schmicdel indicate that Oseen's expression is ralid for Reynolds numbers up to approximately 1 ; above this limit, as for the sphere, the correction is too great.

\section{Cylinders}

In the analysis of an infinitely long eylinder moving slowly and in a direction normal to its axis, the conventional theory yields an infinite resistance per unit length, as pointed out by Stokes. However, with the approximation of Oseen, a result is obtained in a form quite different from those already discussed. For the resistance per unit length, Lamb obtained:

$$
\frac{F / l}{4 \pi j V}=\frac{1}{2.00-\log _{e}(\Omega}
$$

in which $R$ is based on the diameter of the circular eylinder. For an elliptical cylinder, Bairstow et al ${ }^{31}$ obtained a more general result, for motion parallel to either of the two principal axes of the ellipse.

It should be noted that results of the type represented by Eq. (16) give a zero resistance for $\Omega=0$. However, for flow past a fixed cylinder between parallel plates, the resistance was found by Bairstow:2 to remain constant as the Reynolds number tends towards zero. Also in a series of experiments White: found that the equation for the resistance of a cylinder falling in a restricted medium was similar in form to that for a sphere, and that results of the logarithmic type expressed in $\mathrm{E}_{\mathrm{g}}$. (16) were approached only for containers comparatively very large.

Studies of shapes other than those already mentioned have been described in a number of papers. In a recent summary by Durand ${ }^{3}$ the effects of shape were summarized from a study of some 30 papers. The complex problem of defining an infinitely variable quantity such as shape makes it difficult to draw general conclusions. In accord with others, Durand concluded that the most useful representations of shape were based simply upon ratios of the principal axes of the particle, and he showed that even these could be measured in various ways for irregular particles. Within the Stokes range and for particles of several idealized shapes (each symmetrical with respeet to three mutally perpendicular planes) MeNown and Malaika found that the resistance is approximately equal to that obtained theoretically for cllipsoids of the same proportions.

\section{ORIENTATION}

It is evident from Fig. 4 that the value of $K$ is indeed dependent on orientation. For example, a spheroidal particle with one axis four times the other two would fall with a velocity equal to that of a sphere of the same volume and density if the long axis were vertical, and only $3 / 4$ as fast wilh the long axis horizontal. For Reynolds numbers greater than about 0.1 , numerous experimenters have found that only one orientation is stable, riz., that with the maximum cross section normal to the direction of motion. However, it has also been observed that any orientation is stable within the Stokes range.

For symmetrical shapes such as ellipsoids, Gans ${ }^{2}$ superimposed the linear solutions for the motions parallel to the principal axes. As there is no torque in any of the motions, there is none for any orientation. By means of the same concept the variation in resistance with orientation can be determined from the results used in preparing Figs. 4 and 5 . It is 10 be expected that components of motion other than vertical can oceur.

For the cireular disk, only two principal components of motion need be considered, one in

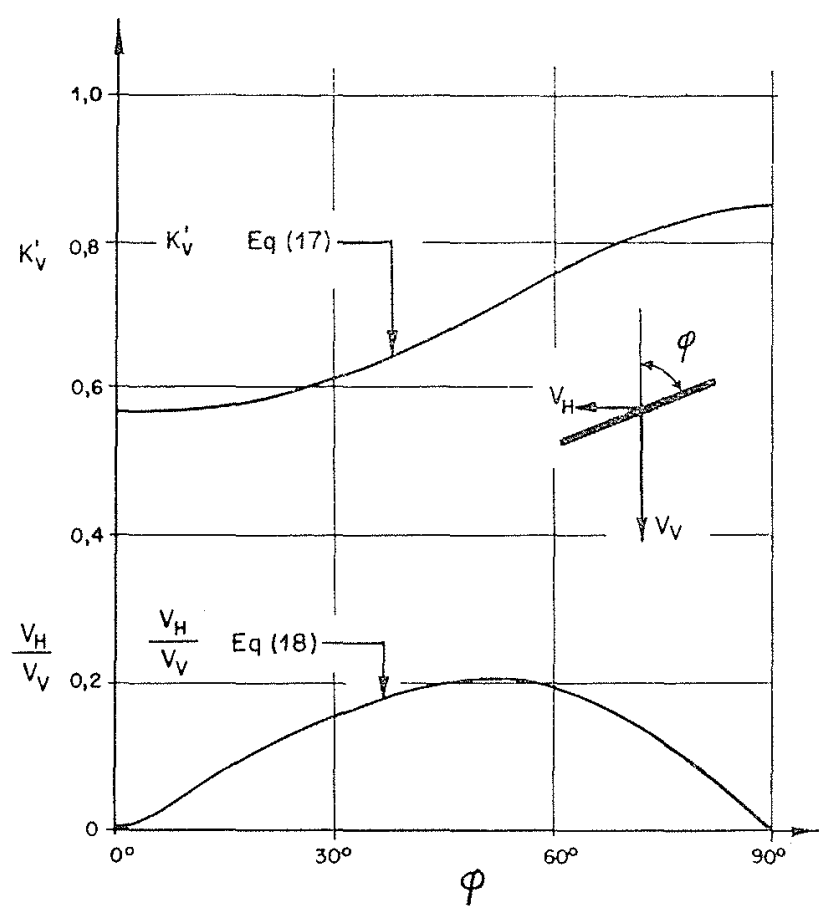

Fia. 6. 
the plane of the disk and the other normal to it. The resistance coefficient for the vertical component of motion of a falling disk can be expressed as a function of $\%$, the inclination of the disk to the vertical:

$$
\mathrm{K}_{\mathrm{Y}}^{\prime}=\frac{8}{3 \pi} \frac{4}{5+\cos 20}
$$

The horizontal eomponent of velocity is simply related to that in the vertical dircetion by means of the expression,

$$
\frac{V_{\text {II }}}{V_{Y}}=\frac{\sin 20}{5+\cos 20}
$$

The rariations of $\mathrm{K}_{\mathrm{V}}^{\prime}$ and $\mathrm{V}_{\mathrm{I}} / \mathrm{V}_{\mathrm{Y}}$ with we shown in Fig. 6. Although the results presented are for the simplest case, they are nonetheless representative of the results to be expected for other shapes. For more nearly spherical shapes the variation of both quantities is less. As shown by Gans, only for needle-like particles are larger values of $V_{\mathrm{I}} / \mathrm{V}_{\mathrm{y}}$ found.

\section{FLUID SPHERES}

It is often stated as an assumption for analyses of viscous flow that there be no slip between the fluid and the solid sphere. Although the validity of this assumption remained in question even in the minds of outstanding scientists unlil the early part of the present century, investigators no longer admit the possibility of a discontinuity in velocity at a boundary unless the size of the particles approaches the spacing of the molecules as for extremely rarified gases or colloidal suspensions. Nevertheless, for the movement of droplets or bubbles, an effective slip occurs because the internal fluid can move relative to the sphere itself. 'Thus, for continuity of velocity, it is not necessary that the velocity at the surface be equal to that of the sphere.

The resistance to the slow motion of a fluid sphere has been determined by theoretical means three different times; Rybezynski 35 and Hadamard 36 published independently the same result in 1911, and Bond ${ }^{37}$, evidently unaware of these works, once again published a calculation of this type of motion in 1927. The result can be written :

$$
\mathrm{K}=\frac{2 u+3 u^{\prime}}{3 \eta+3 \varphi^{\prime}}
$$

in which $\%$ and $u^{\prime}$ are the dynamie viscosities of the external and internal fluids, respectively. If the viscosity of the internal fluid is large compared to that of the external, as for a mist droplet in air, the value of $K$ is approximately unity as for the solid sphere. At the other extreme, for example, an air bubble in a liquid, $K$ is equal to $2 / 3$. Thus, the velocity of aseent of a comparatively inviseid bubble would be 50 per cent greater than that for movement as a solid.

The result expressed in Eq. (19) is so well documented in technical literature that it would hardly be worth further mention were it not for the fact that conflieting experimental results and conclusions have been presented. Even for cases in which the internal viscosity of the fluid is not large compared to that of the external, there are apparently three different kinds of motion possible for a fluid particle : $(a)$ the motion can be the same as for a solid sphere; (b) the particle can be spherical and move as though truly fluid; (c) for larger bubbles, and for comparatively large Reynolds numbers $(\mathcal{R}>100)$, the particle is not spherical and the motion is comparatively unsteady. The third type of motion, which has been summarized by Rosenberg ${ }^{\circ 8}$, is outside the scope of this discussion whereas both of the other two motions, having been found within the Stokes range, form logical parts of this treatment.

The most likely cause of the anomalous behaviol for small Reynolds numbers, as Stokes himself $\approx$, Boussinesq ${ }^{39}$, Duclaux ${ }^{10}$, and others have suggested, is a kind of surface rigidity resulting from contamination of the liquid interface by other substances. The frequent neglect of this important factor is surprising indeed, as stokes wrote, a few paragraphs after his classic equation: "Possibly the determination of the velocity of ascent of very small bubbles may turn out to be a good mode of measuring the amount of friction in the superficial film of a liquid, if it be true that forces of this kind have any existence".

Boussinesq calculated the effect of a "surface viscosity", and obtained the expression:

$$
K=\frac{2 \varepsilon+\left(2 u+3 u^{\prime}\right) d}{2 \varepsilon+\left(3 u+u^{\prime}\right) d}
$$

in which $s$ is a coefficient of surface viscosity. Although no direct method for the evaluation of $\varepsilon$ exists, Eq. (20) indicates that the terms involving the viscosities become relatively less important as the diameter of the sphere decreases. Thus, for a given degree of contamination some criti- 
cal radius should exist below which the liquid sphere would move as a solid.

In studies of the physical chemistry of surfaces ${ }^{41}$, it has been demonstrated that foreign matter will collect on an interface, and that a layer one or more molecules thick will prevent free circulation at the surface. In place of a uniform coefficient of surface viscosity, it is probable that the contaminating particles collect at the rear of the sphere, and, being unable to leave, form a kind of protective shell increasing in size until the particle is effectively enclosed, Thus the surface of the particle can be fluid, effectively solid, or partly fluid and partly solid as far as the internal circulation of the fluid is concerned (see Fig. 7). That the effect of contamination can be sufficiently great to cause this occurrence has been demonstrated by Smith and Crane (see Duclaux). In most experiments with bubbles or droplets, the expected transition from the solid to the fluid has been found to occur with increasing size, but there is little system apparent in the occurrence. Rosenbers

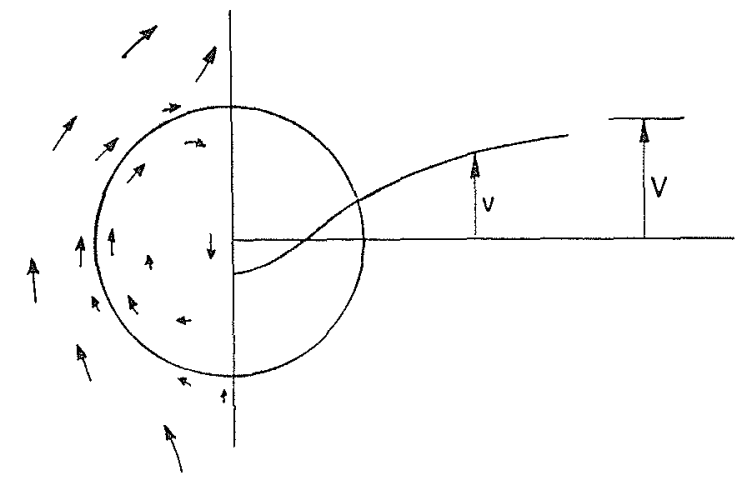

(a) Uncontominated interfoce interface non contaminée concluded from Allen's data and his own that a Reynolds number of 70 characterises the transition, whereas Bond and Newton ${ }^{42}$ found various values of $\left(\Omega\right.$ between $10^{-\tau}$ and $10^{-2}$ for four different combinations of gases and liquids. In experiments for low Reynolds numbers Silvey 43 found no "Hadamard effect" and concluded that Eq. (19) did not hold for mercury droplets in castor oil.

It is quite possible that different degrees of surface contamination together with various surface tensions could cause the scatter in the experimental results. Also, as the bubble size increases, the hydrodynamic stability of the motion decreases, and even a fully contaminated surface would be broken down eventually. It is to be expected that a criterion for the complete definition the transition between the two types of motion would be complex, as it would presumably include the effects of contamination, surface tension, viscosity, and inertia. For the present, it is possible to give only a qualitative description of this phenomenon.

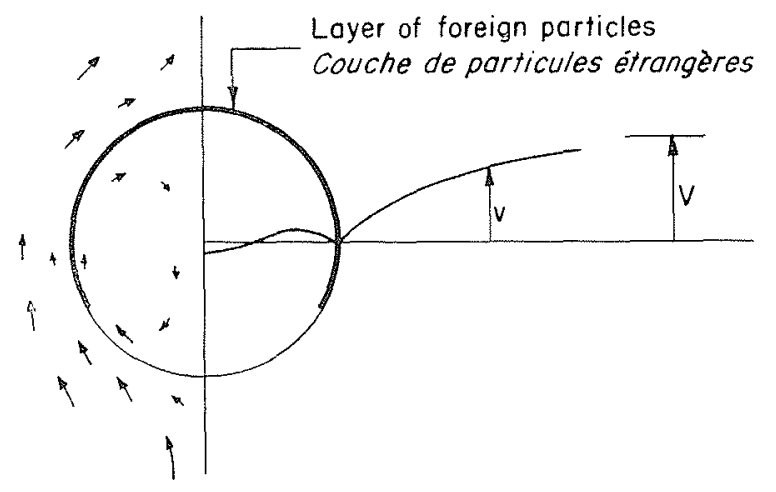

(b) Partially contominated interface interfoce partiellement contaminée

\section{RÉSUME}

Modifications of the Stokes theory for falling particles have been presented for a varicty of boundary conditions. From numerous experiments, information is at hand for delimiting the applicability of the various theories and for enlarging the region of known performance.

The effect of the Reynolds number is relatively well defined, and Oseen's method of including inertia effects if small has been utilized in studies of a variety of shapes and boundary conditions.

The effect of a cylindrical container on the fall of a sphere along the axis of the cylinder is known for a wide range of Reynolds numbers, and for the entire range of sphere-to-cylinder diameter ratios. Additional limits to the effective extent of the fluid such as plane boundaries or other falling spheres have been studied.

The slow motion of cylindrical and ellipsoidal particles has been computed. The importance of particle orientation has been demonstrated quantitatively for ellipsoids and disks and the stability of orientation has been investigated.

Small fluid spheres have been found to move sometimes as though solid and sometimes as though fluid, with variation in surface contamination being the probable cause of the anomalous behavior. 


\title{
Particules en mouvement lent
}

\author{
PAR J. S. MCNOWN \\ STAGLARE FULBRGGT AU LABORATOHE D'HYDMAULIQUE NRYRPL, GRENOBLE \\ DIRECTEUR-ADJOINT DE L'NSTTTUT DE RECHENGHES HYDRAULIQUES DE TOWA-CITY (U.S.A.)
}

English text, p. 701.

Se reporter au texte anglais, p. 701, pour les figures

\section{NOTATIONS EMPLOYÊES}

a Demi-axe de l'ellipsoïde orienté selon la direction du mouvement.

$b, c$ Demi-axes de l'ellipsoïde normaux à la direction du mouvement $(b \geqslant c)$.

d Diamètre de la particule sphérique.

$d^{\prime}$ Diamètre du disque circulaire.

D Diamètre du récipient cylindrique.

$F$ Force extérieure agissant sur la particule.

k. Coefficient.

K Coefficient de résistance (F/ $3 \pi u \mathrm{Vd}$ ).

L. Distance entre deux limites planes parallèles.

$\mathcal{R}$ Nombre de Reynolds de la particule (Vd/v).

$\Omega^{\prime}$ Nombre de Reynolds du fluide (VD/y ou $\mathrm{Vs} / \mathrm{y})$. $s$ Distance des centres de deux particules.

Distance du centre de la particule à un plan.

$\checkmark$ Vitesse de la particule.

$\varepsilon$ Coefficient de viscosité de surface.

- Angle formé par la verticale et la ligne des centres de deux sphères.

v. Viscosité dynamique d'un milieu fluide.

y' Viscosité dynamique d'une particule fluide.

$\checkmark$ Viscosité cinématique du fluide $(\mu / \varrho)$.

- Densité du milieu fluide.

$?^{\prime}$ Densité de la particule.

- Inclinaison du plan du disque sur la verticale.

\section{INTRODUCTION}

Il y a juste un siècle que STokss a présenté an monde scientifique sa remarquable théorie sur le " frottement interne des fluides " ${ }^{1}\left({ }^{*}\right)$, si souvent utilisée depuis dans les recherches. Le résultat peut-être le plus connu de cette théorie est la simple équation du mouvement d'une sphère 2 , justement appelé "loi de Stokes ". Le calcul est valable pour des sphères solides se déplaçant très lentement dans un fluide homogène et infini. L'importance de ces conditions restrictives a été étudiée par divers auteurs; c'est ainsi qu'on a considéré des vitesses supéricures à celles du “ domaine de STores $"\left({ }^{\star *}\right)$, l'influence des conditions aux limites, ou

(*) Ces chiffres se rapportent a la bibliographie p. 719.

(*) Pour faciliter l'exposé, nous emploierons désormais l'expression « domaine de Stokes » pour désigner l'ensemble des conditions pour lesquelles les méthodes d'une forme non sphérique et le comportement des particules fluides. Des études et des mises au point pour les faibles valeurs du nombre de Reynolds ont été présentés par Syoluchowski ${ }^{3}$, Osfen ${ }^{4}$, WeysSENHOFF $\overline{5}$, SCHILLER ${ }^{0}$ et LAMB 7 , entre autres, mais à la suite de diverses recherches plus récentes, dont quelques-unes sont encore inédites, ces études se sont révélées insuffisantes.

Il nous paraît préférable de résumer les résultats essentiels en modifiant l'expression de la loi de SToKes $\left(^{* *}\right)$ par l'insertion du facteur $\mathrm{K}$ dans l'équation classique qui devient :

d'analyse de Stokes sont applicables, c'est-à-dire les conditions permettant de négliger les forces d'inertie sans introduire d'erreurs appréciables.

$\left({ }^{* *}\right)$ Les équations contenues dans ce texte et celles qui se rapportent au sujet sont données en Appendice. 


$$
\mathrm{F}=3 \pi \mu \mathrm{Vd} . \mathrm{K}
$$

dans laquelle w est la viscosité du fluide, V la vitesse constante de la particule, $d$ son diamètre et $F$ la force extérieure produisant le mouvement (généralement le poids apparent de la particule). Le coefficient sans dimension $K$, qui est le rapport des forces extérieures aux forces de viscosité, peut à juste titre etre appelé nombre de STokns. Par définition, sa valeur numérique est égale à 1 pour un mouvement répondant aux diverses conditions imposées par Stokes. On peut encore considérer $K$ comme étant une fonction d'un ou plusieurs des divers facteurs qui peuvent entrainer des diffèrences avec la loi de Srokes : les effets d'inertie, s'ils ne sont pas faibles, les conditions aux limites, la forme de la particule et mème sa fluidité dans le cas des gouttes ou des bulles.

Pour des mouvements aux faibles nombres de Reynolds $\left({ }^{* * *}\right)$, le parametre $K$ est préférable au classique coefficient de trainée car il varie peu avec le nombre de Reynolds. Si les accélérations sont négligeables, employer une relation faisant intervenir leur valeur relative est de peu d'utilité.

Ainsi, la relation $K=1$ caractérise d'une facon plus précise le mouvement d'une sphere en accord avec les hypotheses de Strokes que ne le fait la relation $C_{R}=24 / R$. D'une facon tout a tait analogue, on pourrait définir un nombre de Poisenille qui serait une constante pour l'écoulement laminaire dans un tube circulaire au lieu d'un coefficient de pertes de charge qui varie artificiellement avec le nombre de Reynolds. Parce que plus significatif et plus pratique, nous emploierons $K$ dans l'étude des différentes modifications de la loi de S'Tokes.

Sans doute, $K$ varie-t-il notablement avec $\mathcal{R}$ si ce dernier dépasse environ 0,1 ; cette variation est la plus connue parmi celles déja mentionnées. Les travaux d'Oseex et Golosters s et les nombreux résullats expérimentaux sont si bien cxposés dans la litiérature technique 6,9 que nous ne les reverrons pas en détail ici. Mais même pour l'étude particulière le cel effet, tant que l'on s'attache aux écarts par rapport à la loi de Sroxes pour des nombres de Reynolds relativement faibles, le paramètre $K$ apparait préférable au coefficient de traînée. Ainsi le résultat d'OSEen, qui indique l'importance des forces d'inertie pour des nombres de Reynolds inférieur's à l'unité, peut s'exprimer facilement par :

$$
\mathrm{K}=1+\frac{3}{16} \ll R
$$

Les effets autres que ceux dus aux rariations du nombre de Reynolds ont été étudiés théoriçuement ou expérimentalement. Les résultats d'expérience ont permis de définir le domaine d'application des théories, de préciser les phénomènes au delà de ce domaine et de donner des renseignements pour les cas où on peut difficilement prendre en considération les condicions aux limites.

Les applications des études sur un tel sujet semblent être sans limite. Dans les sciences naturelles, le géologue, l'océanographe, le plyysicien et le météologue prennent grand intéret à ces problèmes, ainsi que dans le domaine des sciences appliquées l'hydraulicien, le métallurgisie, l'ingénieur chimiste et bien d'autres. Même dans les sciences biologicques, Ia vitesse de chute est importante pour les études sur le sang et les suspensions diverses. Avec un champ aussi vaste, il ne peut $y$ avoir de résumé complet mème du point de vue bibliographique, ef notre étude est limitée à quelques-mos des cas les plus importants pour lescuels nos connaissances sont assez bien établies. En plus d'un résumé des travaux pertinents dejà publiés, nous présentons les résultats de nouveaux calculs et expériences sur les effets de l'orientation de la particule et de certaines condilions aux limites.

Cette étude a été commencée à l'Institut de Recherches Hydranliques d'Jowa et terminée au Laboratoire d'Hydraulique Neyrpic. L'auteur a recu une aide matérielle des membres du Laboratoire Neyrpic dans la recherche et l'obtention des références nécessaires, la préparation des figures et des appendices, et la fraduction du texte.

\section{INFLUENCE DES CONDITIONS AUX LIMITES DU DOMAINE FLUIDE}

Comme la réalisation d'un fluide infini considéré par STokes est pratiquement impossible, de nombreuses études ont été consacrées à l'influence de conditions aux limites différentes. Des theories ont été proposées et de nombreuses expériences entreprises dans le but d'évaluer les corrections à apporter dans le cas d'une particule se déplaçant au roisinage de parois fixes ou d'autres particules. Grâce aux résultats de ces études, on peut évaluer l'importance de la correction pour plusieurs cas relativement simples.

(***) Nous définions le nombre de Reynolds en utilisant le diametre $d$ de la sphere $R=V d / v$.

\section{LIMTTE CYLINDRIQUE}

Le problème le plus courant est celui de la détermination de l'influence de la paroi d'un cylindre sur une sphère se déplaçant suivant l'axe de symétrie de ce cylindre, probleme rencontré dans les mesures de viscosité, les expériences de vitesse de chute et diverses recherches de laboratoire. Ies théories et les expériences relatives à cette question sont nombreuses depuis le travail classique d'AlIEN 10 en 1900 , et, me dizaine d'années après, ceux d'Ar-

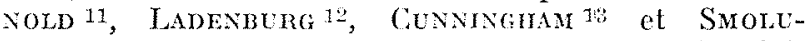
cHowskr. Depuis lors, maintes etudes ont été faites et des synthèses ont été présentées par Scrmruer et Merringtox $1 \%$. Dans me étude récente exé- 
culée a l'Institut de Recherches Hydrauliques d'Iowa ${ }^{15}$, le champ d'investigation a été étendu au cas où le diamètre de la sphère est voisin de celui du cylindre.

Dans une étude théorique, LADEABuRG, en suivant une méthode présentée par LonENTz ${ }^{16}$, a obtenu une expression approximative pour l'influence des parois cylindriques. Faxex ${ }^{17}$ est allé beaucoup plus loin en introduisant des corrections d'ordre plus élevé pour l'influence du rapport $d / \mathrm{D}$ ) (des diamètres de la sphère et du cylindre) et, orientant son étude dans la voie indiquée par OSEeN, en considérant l'effet des forces d'inertie.

Pour de très faibles valeurs du nombre de lieynolds et du rapport $d / D$, le résultat de Faxex (voir Appendice) se réduit à :

$$
\mathrm{K}=1+2,1 \frac{d}{\mathrm{D}}
$$

Il a précisé que son résultat diffère du coefficient 2,4 obtenu par Ladenburg par suite d'une erreur de calcul de ce dernier.

On peut faire une comparaison intéressante entre les résultats obtenus pour des récipients sphériques et cylindriques, la particule se déplaçant dans le premier cas au voisinage du centre de la sphère it l'instant considéré. Quoiqu'une limite sphérique ne présente en elle-même qu'un intérêt académique, Ie fait qu'elle se rapproche étroitement de la limite cylindrique dans la région la plus importante justifie son calcul effectué par Cunvisghar. Il a obtenu une expression exacte pour le cas simple d'une limite constituée par une sphère concentrique. Ce résultat est présenté en Appendice. L'expression devient, au second ordre :

$$
\mathrm{K}=\mathbf{1}+\frac{9}{4} \frac{d}{\mathrm{D}}+\left(\frac{9}{4} \frac{d}{\mathrm{D}}\right)^{2}
$$

Evidemment, l'effet dû à une paroi sphérique devrait être supérieur à celui d'une paroi cylindrique, et le résultat de Ladenburg apparaît alors indubitablement trop fort tandis que celui de FAxEx paraît vraisemblable.

Une théorie approchée pour le mouvement d'une sphère dans un tube cylindrique de diamètre sensiblement égal a été établie par l'auteur et ses collaborateurs ${ }^{15}$. On admet que l'écoulement entre la sphère et le cylindre est plan et varie lentement dans ce plan et que la résistance effective est localisée dans un petit espace au voisinage de l'écuateur de la sphère. Le calcul aboutit à l'équation suivante :

$$
\mathrm{K}=1,66\left(1-\frac{d}{\mathrm{D}}\right)^{-5 / 2}
$$

On peut adapter cette analyse au cas où la sphère se meut non pas suivant l'axe, mais excentriquement avec un point de contact permanent roulant le long d'une génératrice du cylindre. Dans ce cas, la distance entre le cylindre et l'équateur de la sphère varie de zéro à $\mathrm{D}-d$ en première approximation en accord avec la quantité $(\mathrm{D}-d)(1+\cos \theta) / 2$, dans laquelle $\theta$ est mesuré dans le plan de l'équateur. Pour ce type de mouvement, le résultat est :

$$
\mathrm{K}=0,868\left(1-\frac{d}{\mathrm{I})}\right)^{-5 / 2}
$$

la rèsistance étant à peu près moitié de celle obtenue dans le cas précédent.

Les diverses expériences faites avec une sphère tombant à l'intérieur d'un cylindre vertical permettent de comparer les théories précédenies et de définir leurs domaines d'application respectifs. Les courbes déduites des expériences sont tracées sur la figure 1 et permettent une comparaison avec les courbes théoriques pour des rapports de diamèires variant de 0 à 0,4 . On peut voir facilement que les approximations linéaires ne sont justifiées que dans un domaine très limité tandis que celles d'ordre supérieur cadrent assez bien avec la courbe expérimentale limite (aux faibles nombres de Reynolds) pour la plupart des valeurs de $d / \mathrm{D}$ indicuées sul la figure.

Par interpolation on a déduit des résultats expérimentaux (surtout ceux obtenus à Iowa ${ }^{15}$ ), les courbes $\mathcal{R}=$ constante. Il est remarquable que pour les valeurs croissantes de $d / \mathrm{D}$ ces courbes tendent vers la courbe limite correspondant aux mouvements pour lesquels les forces d'inertie sont négligeables. Ainsi la valeur critique de $\mathcal{R}$ correspondant à la limite supérieure du domaine de Srokes croit lorsque $d / \mathrm{D}$ décroît. La correction de Faxen relative à l'influence des forces d'inertie a été mise en évidence par le tracé de la courbe théorique pour $\mathbb{R}=1$. Le fait expérimental que cette influence décroit lorsque $d / \mathrm{D}$ croît n'est pas aussi caractérisé dans les calculs théoriques. On voit donc que la correction de Faxen est trop forte.

Au cours des études réalisées à l'Institut de Recherches Hydrauliques d'Iowa, les résultats furent étendus aux valeurs de $d / \mathrm{D}$ voisines de 1 (fig. 2). Pour les valeurs de $d / \mathrm{D}$ supérieures à 0,95 , les résultats expérimentaux correspondent bien à l'équation (5) si le tube est exactement verical et si $\mathscr{R}$ est très petit (inférieur à environ 0,001). Si l'une des deux conditions précédentes n'est pas remplie, la sphère tombe excentriquement. en roulant et la résistance obtenue est en accord avec l'équation (6), comme indiqué sur la figure 2.

\section{LIMITES VERTICALES PLANES}

Les mouvements lents d'une particule sphérique près d'un plan vertical et entre deux plans verticaux ont éé étudiés respectivement par Lorbatz ${ }^{16}$ et Faxex 18. Dans le cas d'un seul plan, on peut exprimer le résultat sous la forme suivante :

$$
\mathrm{K}=1+\frac{9}{32} \frac{d}{s}
$$

dans lacquelle $s$ est la distance du centre de la sphère au plan. A un ordre d'approximation plus élevé, Oseen ${ }^{4}$ a obtenu une équation qui tient compte également des faibles effets de l'inertie par des termes variables avec la quantité Vs/y. Dans ce mouvement, il a trouvé une composante horizontale qui dépend aussi de ce dernier rapport.

Pour une particule sphérique tombant symétriquement entre deux plans parallèles, le résultat de Faxen est, en première approximation : 


$$
\mathrm{K}=1+\frac{d}{\mathrm{~L}}
$$

où $L$ est la distance entre les parois. Il a aussi calculé une forme modifiée de ce mouvement dans laquelle la particule est à une distance $L / 4$ d'une des parois (voir Appendice).

\section{LIMITE HORIZONTALE PLANE}

Le mouvement irrégulier d'une sphère tombant vers un plan horizontal a élé étudié par LoRENTz. Dans ses calculs, il a négligé les effets d'inertie, bien que la vitesse de la sphère change, et il est arrivé au résultat :

$$
\mathrm{K}=1+\frac{9}{16} \frac{d}{s}
$$

dans lequel $s$ est encore la distance du centre de la sphère au plan. Les résultats expérimentaux exposés par Altrichter et Lustig ${ }^{19}$ sont en bon accord avec ceux de la théorie de Lonentz, si la valeur de $s / d$ est supérieure à 15 environ. Pour de plus faibles valeurs de $s / d$, l'effet trouvé expérimentalement est beaucoup plus grand que celui obtenu d'après l'écquation (9).

\section{CAS DE DEUX OU PLUSIEURS SPHËRES}

Si plusieurs sphères se déplacent en chute libre dans un fluide, il y a une interaction réciproque. Comme chaque sphère tend à entraîner une partic du fluide avec elle, la vitesse de chacune croîl à cause du mouvement des autres si le fluide peut ètre considéré comme infini. Au contraire, dans un fluide limité, il y a un écoulement ascendant compensateur de telle sorte que le débit à travers un plan horizontal quelconque est nul. Près de la sphère, dans ce dernier cas, la vitesse induite est dirigée vers le bas alor's qu'un peu plus loin elle est dirigée vers le haut. La vitesse d'une sphère voisine peut donc soit croìtre soit décroître, et on peut ainsi expliquer les résultats contradictoires de SuDny 20 et GHall 21 concernant les mouvements de ce type. Pour un grand nombre de particules plus ou moins également espacées à travers le fluide, l'effet résultant serait une réduction en vitesse moyenne ou bien une augmentation de la valeur de $K$.

SMoluchowskr ${ }^{3}$ a calculé les forces s'exercant sur chacune de deux sphères identiques se déplaçant dans un fluide infini. Par une superposition des deux distributions de forces que l'on trouve en considérant successivement chacune des sphères comme étant fixe tandis que l'autre est en mouvement, il a obtenu deux composantes qu'on doit combiner avec la résıstance de Srokes. L'une est verticale et égale à :

$$
3 \pi \text { v } \mathrm{V} d\left[\frac{3}{8}-\frac{d}{s}\left(1-\frac{3}{8} \frac{d}{s}\right)\right]
$$

L'antre agit le long de la ligne des centres des sphères et dans la direction de la sphère la plus basse, et est égale à :

$$
3 \pi: \mathrm{V} d\left[\frac{3}{8} \frac{d}{s}\left(1-\frac{9}{8} \frac{d}{s}\right)\right] \cos 0
$$

dans laquelle 0 est l'angle entre la ligne des centres et la verticale. Si les deux sphères sont sur le même plan horizontal, la deuxième composante est nulle et le résultat correspondant s'exprime comme suit :

$$
\mathrm{K}=1-\frac{3}{8} \frac{d}{s}+\left(\frac{3}{8} \frac{d}{s}\right)^{2}
$$

Pour le cas de deux sphères sur une même verticale, les deux composantes sont co-linéaires et lo résultat correspondant est :

$$
\mathrm{K}=1-\frac{3}{4} \frac{d}{s}+\left(\frac{3}{4} \frac{d}{s}\right)^{2}
$$

L'équation (11) peut être aussi obtenue comme cas particulier des résultats calculés à un ordre plus élevé par FAxen pour deux particules inégales, ou par Daml (voir FAxes 22). Dans un autre calcul, STrmSON et JEFFERY 23 ont trouvé des valeurs de $\mathrm{K}$ correspondant bien à l'équation (11) lorsque la distance entre les sphères est supérieure à trois diamètres. Mais il est à remarquer que les conditions de calcul des équations (7) à (11) ne sont pas valables si l'espacement est inférieur à quelques diamètres.

Sur la figure 3 , les résultats des calculs théoriques sont comparés avec ceux des expériences de Bamm $2: 4$ pour le cas de deux sphères et pour le cas d'une sphère près d'un plan vertical. La divergence assez grande des résultats provient en partie de la présence de la paroi et du fond du récipient. Bammr a trouvé que pour deux particules l'écoulement ascendant du fluide peut conduire à des valeurs de $\mathrm{K}$ supérieures à 1 , contrairement au résultat théorique de SMoluchowskr pour un fluide infini. Dans quelques expériences isolées, Gralr a aussi trouvé des valeurs de $\mathrm{K}$ supérieures et d'autres inférieures à l'unité pour deux sphères.

Les considérations ci-dessus sont tout à fait applicables si l'on considère un grand nombre de sphères. Dans le cas d'un nuage isolé de sphères, la vitesse de chaque particule augmenterait, alors que dans le cas de particules plus ou moins uniformément distribuées dans tout le fluide cette vitesse diminuerait. Ce dernier type de mouvement est à peu près idenfique à celui des études de CunnrngHaM, SMoluchowski, l'autenr et ses collaborateurs et Burgers 25. Les résultats s'expriment d'une façon commode sous la forme :

$$
\mathrm{K}=1+k \frac{d}{s}
$$

dans laquelle $s$ est l'espace moyen entre les particules et $k$ est un coefficient constant qui dépend des diverses hypothèses faites dans les calculs. On a obtenu des valeurs de $k$ de 0,7 à 2,2. D'après ces résultats, on pent estimer l'effet de la concentration des sédiments sur la vitesse de chute. Pourtant, on n'a considéré que des particules de même dimension et uniformément réparties. Les effets d'une répartition quelconque et ceux de diverses dimensions devraient être déterminés expérimentalement. 


\section{FORME DE LA PARTICULE}

Bien que la forme sphérique soit de beancoup la plus simple à étudier soit par l'analyse, soit par l'expérience, on a souvent besoin de renseignements sur les autres formes et des recherches sur ce sujet ont été effectuées particulièrement par les hydratliciens, les géologues et les techniciens du béton. Des complications supplémentaires apparaissent car l'orientation devient un facteur important pour les particules non sphériques et parce qu'une seule dimension ne suffit plus à les définir. Les ellipsoïdes et les cylindres ont été dudiés analytiquement et des expériences ont été effectuées sur un grand nombre de formes géométriques artificielles ainsi que sur des corps de formes naturelles telles que des grains de sable.

\section{ElLIPSOÏDES}

Les équations fondamentales du mouvement lent d'un ellipsoïde ont été données par OBERBEck 26 en 1876 et sont signalees par OsEen $t$ et LAMB ?. Ces équations nécessitent l'emploi des intégrales elliptiques pour leur résolution et, avant une récente étude publiće en collaboration avec Malarka 27 on n’avait déterminé la résistance que dans les cas spéciaux des disques et des ellipsö̈des de révolution 28 . Cette étude 27 établit les équations et les courbes permettant l'évaluation de la résistance d'un ellipsoïde se déplaçant suivant l'un quelconque de ses trois axes principaux. Ces résullats sont représentés graphicuement figure 4 , le demi-axe a étant pris parallèle à la direction du mouvement, et $b$ et $c$ étant choisis de sorte que $b \geqslant c$. La valeur de K peut être défnie par l'équation :

$$
\mathrm{K}=\frac{16}{3 d \zeta}
$$

dans laquelle $d$ est le diamètre de la sphère ayant le même volume,

$$
d=2 \sqrt[3]{a b c}
$$

et $s$ est, en général, exprimable en termes de fonctions ellipticues.

En tout, il y a huit cas différents, comme l'indi(que la figure 4 , les équations finales pour $s$ etant différentes pour chaque cas (voir l'Appendice); le champ possible se divise alors en : a) un seul point pour la sphère; $b$ ) quatre courbes pour les ellipsoïdes de révolution; c) trois régions pour les ellipsoïdes en général. Un résultat intéressant de ce calcul est la détermination de la forme ellipsoïdale de résistance minima pour un volume donné; ce n'est pas la sphère mais un ellipsöde de révolution dont le grand axe est dirigé dans le sens du mouvement et est: sensiblement le double des deux autres axes. La valeur minimum correspondante de $K$ est 0,955 .

Si le rapport des axes $(a / \sqrt{b c)}$ devient soit très petit (cas des disques), soit très grand (cas des bâtonnets), $K$ devient très grand et tend vers l'infini.

\section{Disques}

Le mouvement d'un disque circulaire, cas limite des ellipsoïdes, a aussi été étudié théoriquement et expérimentalement. Dans ce cas, lorsqu'n des trois axes tend vers zéro, to diamètre de la sphère èquivalente tend vers zéro et $K$ tend vers l'infini (résultat logique puisque la vitesse d'une telle particule en chute libre serait nulle). Pour les comparaisons, il est donc utile d'employer le diamètre du cercle comme longueur de référence ou, dans le cas plus général d'un discue elliptique, le diamètre d'un cercle de même surface. En notant cette longueur $d^{\prime}$ et le coefficient correspondant $K^{\prime}$, on pent écrire :

$$
\mathrm{K}^{\prime}=\frac{16}{3 d^{\prime} \zeta}
$$

L.a variation de $\mathrm{K}^{\prime}$ avec le rapport des deux axes non nuls est indiquée dans la figure 5 pour les trois directions principales : a) normalement au plan du discue; b) dans la direction. du grand axe; c) dans la direction du petit axe. Les valeurs limites pour le disque circulaire sont $8 /(3 \pi)$ pour le premier cas, et $16 /(9 \pi)$ pour les deux autres. Une fois de plus, la valeur minimum du coefficient de résistance apparait pour le cas d'un mouvement parallèle au grand axe lorsque ce dernier est approximativement deux fois plus grand que le petit axe.

Pour les nombres de Reynolds (basés sur $d^{\prime}$ ) supérieurs à 0,1 les résultats pour le disque diffèrent de ceux de la loi de STokes modifiée, a peu près de la même façon que dans le cas de la sphère. Ce phénomène a aussi été étudié par Oseen ${ }^{+}$et il a obtenu le résultat théorique:

$$
\mathrm{K}^{\prime}=\frac{8}{3 \pi}\left(1+\frac{\Omega^{\prime}}{2 \pi}\right)
$$

pour le disque circulaire se déplacant normalement à son plan. Les expériences de Schmuene 29 indiquent que l'équation d'OsEen est valable pour les nombres de Reynolds allant jusqu'à 1 environ; audessus de cette limite, comme pour la sphère, la correction est trop grande.

\section{Cyunndres}

Pour l'analyse du mouvement lent et normal ì son axe d'un cylindre infiniment long, la theorie classique donne une résistance infunie par unité de longueur, comme S'rokes, lui-même, l'a mentionné. Pourtant, avec l'approximation d'OseEx, on obtient un résultat qui est assez différent dans sa forme de ceux déjà mentionnés. Pour la résistance par unité de longuenr, LAmB: a obtenu:

$$
\frac{\mathrm{F} / l}{4 \pi \mu \mathrm{V}}=\frac{1}{2,00-\log _{e} \mathcal{Q}}
$$

dans lequel $R$ est basé sur le diamètre du cylindre. Pour un cylindre ellipticue, Barrstow, Cave el LANG 31 ont obtenu un résultat plus général pour un mouvement parallèle à l'un ou l'autre des deux axes 
principaux de l'ellipse. Il est à remarquer que les résultats du type représenté par l'équation (16) donnent une résistance nulle pour $(\Omega=0$. Cependant, pour un écoulement autour d'un cylindre fixé entre deux parois verticales, la résisiance trouvée par BAIRstow 32 reste constante lorsque le nombre de Reynolds tend vers zéro. A la suite d'une série d'expériences, White 33 a trouvé que l'écluation de la résistance d'un cylindre se déplaçant en chute libre dans un fluide limité, était semblable à celui de la sphère et que les résultats en $\log \mathrm{R}$ du type de l'équation (16) ne sont valables que pour des cylindres très petits par rapport à l'étendue du fluide.

Des études de formes autres que celles déjà mentionnées ont été présentées dans un certain nombre d'articles. Dans une mise au point récente, Durand $3 t$ a présenté un résumé des effets de la forme à partir d'une trentaine de références. La complexité du problème consistant à définir une qualité aussi variable que la forme rend difficile l'énoncé de conclusions générales. En accord avec d'autres auteurs, DURAND a conclu que les représentations les plus utiles de la forme sont basées simplement sur les rapports des axes principaux de la pàrticule, et il a précisé que même ceux-ci pouvaient être mesurés de différentes facons dans le cas de parficules irrégulières. Dans le domaine de STokes, l'anteur et MaLAIKA ont trouvé que pour quelques particules de formes idéales (chacune symétrique par rapport à trois plans perpendiculaires), la résistance est approximativement égale à celle obtenue théoriquement pour les ellipsoïdes de mêmes proportions.

\section{L'ORIENTATION}

Il est évident, d'après la figure 4, que l'orientation d'une particule non sphérique peut modifier sa résistance. Par exemple pour une particule en forme d'ellipsoïde de révolution avec un grand axe quatre fois plus grand que le petit axe, la vitesse de chute esit égale à celle d'une sphère de même volume et densité si le grand axe est parallèle au mouvement mais n'atteint que les trois quarts de cette valeur, si le grand axe est horizontal. Pour des nombres de Reynolds plus grands que 0,1 environ, de nombreux expérimentateurs ont trouvé qu'une seule orientation est stable, celle correspondant à la section de surface maximum à la chute. Remarquons cependant qu'on a observé que toute orientation est stable dans le domaine de Stores.

Pour des formes symétriques telles que les cllipsoïdes, Gans 28 a combiné les solutions linéaires obtenues pour les chutes parallèles aux axes principaux. Puisqu'il n'y a pas de couple dans ces cas, il n'y en a pas non plus pour une orientation quelconque. De plus, les variations de résistance avec l'orientation peuvent être déterminées d'après les résultats utilisés pour tracer les figures 4 et 5 . On peut aussi s'attendre à ce que le mouvement présente une composante horizontale.

Pour le disque circulaire, deux composantës seulement doivent être considérées, une dans le plan du disque et l'autre normal à celui-ci. Le coefficient de résistance pour le mouvement vertical du disque tombant peut être défini comme une fonction de 0 , l'inclinaison du disque sur la verticale.

$$
\mathrm{K}^{\prime}=\frac{8}{3 \pi} \frac{4}{5+\cos 2 \%}
$$

Le rapport des composantes horizontale et verticale de la vitesse est donné par l'équation :

$$
\frac{\mathrm{V}_{\mathrm{H}}}{\mathrm{V}_{\mathrm{V}}}=\frac{\sin 2 \varphi}{5+\cos 2 \varphi}
$$

Les variations de $\mathrm{K}^{\prime}$ et $\mathrm{V}_{\mathrm{Y}} / \mathrm{V}_{\mathrm{Y}}$ avec 0 sont mises en évidence sur la figure 6 . On a présenté les résultats pour le cas le plus simple, mais ils sont représentatifs des résultats pour les autres formes. Pour des forme plus proches de la sphère, ces variations sont moins marquées. Comme Gans l'a montré, c'est seulement pour des particules en forme d'aiguille qu'on trouve des valeurs plus fortes de $V_{\mathrm{II}} / \mathrm{V}_{\mathrm{V}}$.

\section{SPHÈRES FLUIDES}

Dans l'étude des écoulements visqueux, on énonce souvent l'hypothèse qu'il n'y a pas glissement au contact entre le fluide et la sphère. Bien que la validité de cette condition soit restée en question même dans l'esprit des savants les plus éminents jusqu'au commencement de ce siècle, les chercheurs n'admettent plus la possibilité d'une discontinuité de vitesse à la surface d'un solide, sauf dans les cas où les dimensions des particules tendent vers celles de l'écartement compris entre les molécules, soit par exemple pour des gaz extrêmement raréfiès, soit pour des suspensions colloïdales. Cependant, dans le cas du mouvement des gouttes et des bulles, il se produit effectivement un glissement, dû au fait que le fluide intérieur peut se mouvoir par rapport à la sphère elle-même. Alors, pour satisfaire la condition de continuité des vilesses, il n'est pas nécessaire que la vitesse en surface soit égale à celle de la sphère.

La résistance, en mouvement lent, d'une sphère fluide, a été déterminée théoriquement à trois reprises : RYBczmssi ${ }^{35}$ et Hadamard 36 ont exposé indépendamment le même résultat en 1911, et BOND ignorant certainement ces travaux, a présenté un calcul sur ce même type de mouvement en 1927. Les trois résultats peuvent s'écrire :

$$
K=\frac{2 u+3 u^{\prime}}{3 u+3 u^{\prime}}
$$

où $\mu$ et $\mu^{\prime}$ sont les viscosités des fluides respectivement extérieur et intérieur. Si la viscosité du fluide intérieur est grande par rapport à celle du fluide extérieur, comme pour une goutte d'eau dans l'air, la valeur de $K$ est approximativement égale à l'unité, et le résultat est le même que pour une sphère solide. A l'opposé pour une bulle d'air dans un liquide, par exemple, $K$ est égal à $2 / 3$. Donc, une bulle dans un liquide relativement visqueux doit 
monter à une vitesse $50 \%$ plus grande que cello qu'elle atteindrait si elle se mouvait comme un solide.

Le résultat exprimé par l'équation (19) a été si souvent discuté dans la littérature technique qu'il ne vaudrait guère la peine de le faire ì cette place si des résultats expérimentaux et des conclusions contradictoires n'avaient été présentés à son sujel. Même pour les cas dans lesquels la viscosite du fluide interieur n'est pas grande par rapport à celle du fluide extérieur, il y a apparemment trois types diférents possibles de mouvement d'une sphère fluide : a) le mouvement peut être le même que pour une sphère solide; b) la particule peut rester sphéricue ef se mouvoir comme si elle était vraiment fluide; $c$ ) pour des bulles plus grandes et pour des nombres de Reymolds relativement grands $(\Omega>100)$, la particule n'est plus sphérique et le mouvenent est relativement irrégulier.

Le troisieme type de mouvement dont ROSExHERG: a donné un résumé sort du cadre de cet article, contrairement aux deux autres mouremonts fui appartiennent au domaine de Strokes.

La cause la plus probable du. comportement anormal aux faibles nombres de Reynolds, comme SToxes lui-même 2, Boussmese ${ }^{30}$, Ductaux to et d'autres l'ont mentionné est une sorte de rigidité superficielle due à une contamination de l'interface liquide par d'autres substances. Le fait que cette cause est si souvent négligée peut paraître surprenant car SToKES écrivit, quelques paragraphes après son équation classique : " La détermination de la vitesse d'ascension de très petites bulles pourrait être un bon moyen de mesurer le frottement dans le film superficiel de liquide, si toutefois de telles forces existent ». Boussineso a calculé l'effet d'une "viscosité de surface " et obtenu l'écuation :

$$
K=\frac{2 \varepsilon+\left(2 \mu+3 u^{\prime}\right) d}{2 \varepsilon+\left(3 \psi+3 u^{\prime}\right) d}
$$

dans laquelle a est le coefficient de viscosité de sulface. Bien qu'il n'y ait aucune méthode directe pour la mesure de $\varepsilon$, d'après l'équation (20), les termes dans lesquels interviennent les viscosités deviennent relativement moins importants lorsque le diamètre de la sphère décroît. Alors, pour un degré de contamination donne, pour toutes valeurs du rayon infé- rieures à unc valeur eritique, les sphères devraient se comporter comme un solide.

Dans des etudes de propriétés physico-chimiquues de surface $t l$, on a montré que les matériaux étrangers se rassembleront sur l'interface et qu'une couche d'une ou plusieurs molécules en épaisseur peut empêcher une libre circulation à la surface. Au lieu d'un coeficient uniforme de viscosité de surface, il est probable que les particules contaminant la surface se rassembleront au dos de la sphère et, etant incapables d'en partir, forment une espèce d'écorce protectrice qui crồ: en surface jusqu'à ce que la particule soit effectivement enveloppée (voir fig. 7). Ainsi, si l'on considère la circulation intérieure du fluide, la surface de la particule peut être fluide, ou identique à un solide, ou un mélange des deux. Le fait que l'effot de l'impureté peut être suffisamment important pour explicfuer ce phénomène a été mis en évidence par Surre el Chaxe (voir Duchaud

Dans la plupart des expériences sur les bulles el les goultes, on a trouvé une transition de solide $i$ fluide si le diamètre angmente, mais le phénomène ne se produit pas systématiquement. RosmenERg a conclu, d'après les données d'Arres et les siennes propres, qu'un nombre de Reynolds de 70 caractérise Ia transition, alors que Bovn et Newrox t2 ont indiqué diverses valeurs de $R$ entre $10^{-7}$ et $10^{-2}$ pour quatre combinaisons différentes de gaz et de fluides. Au cours d'expériences aux faibles nombres de Reynolds, Srlvey 43 'a trouvé aucun " effet d'HADAMARD " et il en a conclu que l'équation (19) n'est pas valable pour les petites gouttes du mercure dans l'huile de ricin.

Il est bien possible que les variations de la teneur en impuretés de la surface et celles des tensions superficielles de la surface puissent être la cause de dispersion des résultats expérimentaux. De plus, lorsque la grandeur de la bulle croît, la stabilité hydrodynamique du mouvement décroît et une surface lout à fait contaminée pourrait éventuellement se rompre. Mais un critérium définissant la transition entre les deux types de mouvement serait complexe parce qu'il devrait comprendre les effets de contamination, de tension superficielle, de viscosité et d'accélération. Pour le moment, il n'est possible de donner qu'une description qualiative de ce phénomène.

\section{RÉSUMÉ}

Des modifications a la loi de Srokes pour les particules en chute libre ont été donnés pour les diverses conditions aux limites. Grâce à de nombreuses expériences, on peut défnir les conditions d'application des diverses théories et étendre davantage le domaine des comportements connus.

L'influence du nombre de Reynolds est relativement bien définie et la méthode d'OSEEN pour l'introduction des petits effets d'accélération a été appliquée à l'étude de diverses formes et conditions aux limites.

L'influence de parois cylindriques sur le mouvement libre d'une sphère suivant l'axe d'un cylindre est connuc pour un large intervalle de nombres de Reynolds et pour toutes les valeurs du rapport des diamètres de la sphère el du cylindre. D'autres limitations au libre mouvement du fluide, telles que la présence de parois planes ou d'autres sphères cn mouvement, ont été étudiées.

On a déterminé le mouvement lent des particules ellipsoïdales et cylindriques. L'importance de l'orientation a été montrée cuantitativement pour les ellipsoïdes et des disques et les conditions de stabilité d'orientation ont été étudiées.

On a enfin mis en évidence que les sphères fluides se meuvent tantôt comme un solide et tantôt comme un fluide, la variation de l'état de contamination de la surface étant la cause probable de ce comportement anormal. 


\section{AP P E D IX}

LIST OF FORMULAS

\section{A P P E N I C E}

\section{FORMULAIRE}

I. -- Stokes' Equations.

f. - Equhtions de Stomes.

Resistance 2: Resistance:

$$
\mathrm{F}=3 \pi \mathrm{V} \mathrm{Vd}
$$

Free fall 2:

Chute libre:

$$
\mathrm{V}=\frac{1}{18} \frac{p^{\prime}-p}{\mu} g d^{2}
$$

Modified equation ${ }^{55}$ Equation modilée :

$$
\mathrm{F}=(3 \pi \bullet \mathrm{V} d) \mathrm{K}
$$

II. - EFfect of SMALL ACCELERATIONS.

II. - INildence des farbles accélérations.

Oseen :

$$
K=1+\frac{3}{16} \Omega
$$

Goldstein s:

$$
\mathrm{K}=1+\frac{3}{16} \text { 凡- } \frac{19}{1280} \boldsymbol{R}^{2}+\frac{71}{20,480} \mathcal{R}^{2} \ldots
$$

iII. - Cylmndrical boundary.

III. - Frontiene CYliNDRIQUE.

(a) $d / D<1$

Ladenburg ${ }^{12}$ :

$$
\mathrm{K}=1+2.4 \frac{d}{\mathrm{D}}
$$

Faxén 17 :

$$
\frac{1}{\mathrm{~K}}=1-\frac{3}{16} \mathfrak{R}-\frac{d}{\mathrm{D}} i\left(\frac{\mathrm{VD}}{\nu}\right)+2.09\left(\frac{d}{\mathrm{D}}\right)^{3}-0.95\left(\frac{d}{\mathrm{D}}\right)^{5}
$$

in which:

$$
\text { dans laquelle: }
$$

$$
\begin{array}{cccccc}
\mathrm{VD} & 0 & 2 & 4 & 8 & 20 \\
\hline v & & & & & \\
f & 2.104 & 1.76 & 1.48 & 1.04 & 0.46
\end{array}
$$

Approximate value:

Valeur approchée :

$$
\mathrm{K}=1+2.1 \frac{d}{\mathrm{D}}
$$

(b) $d / \mathrm{D} \rightarrow 1$

Symmetric motion 15 :

Mouvement symétrique :

$$
\mathrm{K}=\frac{3 \sqrt{2} \pi}{8}\left(1-\frac{d}{\mathrm{D}}\right)^{-5 / 2}=1.66\left(1-\frac{d}{\mathrm{D}}\right)^{-5 / 2}
$$


Asymmetric motion:

Mouvement dissymétrique :

$$
\mathrm{K}=\frac{45 \pi^{2}}{512}\left(1-\frac{d}{\mathrm{D}}\right)^{5 / 2}=0.868\left(1-\frac{d}{\mathrm{D}}\right)^{-5 / 2}
$$

IY. - Spherical boundary.

IV. - Frontuère sphérique.

Cunningham ${ }^{13}$ :

$$
\mathrm{K}=\frac{1+\frac{1}{4}\left(\frac{d}{\mathrm{D}}\right)^{j}}{1-\frac{9}{4} \frac{d}{\mathrm{D}}+\frac{5}{2}\left(\frac{d}{\mathrm{D}}\right)^{*}-\frac{9}{4}\left(\frac{d}{\mathrm{D}}\right)^{j}+\left(\frac{d}{\mathrm{D}}\right)^{0}}
$$

Approximate value:

Valeur approchée :

$$
\mathrm{K}=1+\frac{9}{4} \frac{d}{\mathrm{D}}+\left(\frac{9}{4} \frac{d}{\mathrm{D}}\right)^{2}
$$

V. - Plane boundaries.

One vertical plane.

Lorentz 1e:

Stock ${ }^{6}$ :

$$
\mathrm{K}=1+\frac{9}{32} \frac{d}{s}
$$

$$
\mathrm{K}=\frac{1}{1-\frac{9}{32} \frac{d}{s}}-\left(\frac{d}{4 s}\right)^{3}\left(1+\frac{9}{32} \frac{d}{s}\right)
$$

Oseen ${ }^{4}$ :

$$
\frac{1}{\mathrm{~K}}=1-\frac{9}{8} \frac{d}{4 s}+\left(\frac{d}{4 s}\right)^{3}-\frac{45}{16}\left(\frac{d}{4 s}\right)^{4}-2\left(\frac{d}{4 s}\right)^{5}
$$

Faxén 18 :

$$
\frac{1}{\mathrm{~K}}=1-\frac{3}{16} \mathcal{R}+\frac{9}{8}-\frac{d}{4 s} f\left(\frac{\mathrm{V} s}{2 v}\right)+\left(\frac{d}{4 s}\right)^{3}-\frac{45}{16}\left(\frac{d}{4 s}\right)^{4}-2\left(\frac{d}{4 s}\right)^{\bar{n}}
$$

in which:

dans laquelle :

$$
f\left(\frac{\mathrm{V} s}{2 y}\right)=f(x)=1-\frac{4}{3} x+\frac{23}{16} x^{2}-\frac{16}{9} x^{3}+\frac{317}{864} x^{4}+\frac{8}{9} x^{5}-\left[\frac{25}{24} x^{1}+\ldots\right] \log 1.781-\frac{x}{2}
$$

Two planes parallel and vertical.

Deux plans verticaux et parallèles.

Symmetric:

Symétriques :

Faxén 18:

$$
\frac{1}{\mathrm{~K}}=1-1.004 \frac{d}{\mathrm{~L}}+0.418\left(\frac{d}{\mathrm{~L}}\right)^{3}-0.169\left(\frac{d}{\mathrm{~L}}\right)^{5}
$$

Sphere at quarter-point:

Sphere au cuart de l'interplan :

Faxén 18:

$$
\frac{1}{\mathrm{~K}}=1-0.6526 \frac{4 d}{\mathrm{~L}}+0.1475\left(\frac{4 d}{\mathrm{~L}}\right)^{3}-0.131\left(\frac{4 d}{\mathrm{~L}}\right)^{4}-0.0644\left(\frac{4 d}{\mathrm{~L}}\right)^{5}
$$

Horizontal plane boundary.

Frontiere plane et horizontale.

Lorentz 16

$$
\mathrm{K}=1+\frac{9}{16} \frac{d}{s}
$$


VI. -- TwO OR MORE SPHERES.

Y. - DEUX oU pLUSIEURS sphères.

Two spheres in the same horizontal plane:":

Deux sphères dans le même plan horizontal:

$$
\mathrm{K}=1-\frac{3}{s} \frac{d}{s}+\left(\frac{3}{8} \frac{d}{s}\right)^{2}
$$

Two spheres in the same vertical line:

Deux sphères sur la même vericale: :

$$
K=1 \cdots \frac{3}{4}-\frac{d}{s}+\left(\frac{3}{4} \frac{d}{s}\right)^{2}
$$

Since the extremely complicated expressions of Faxén ${ }^{2}$, Dahl 2 and Stimson and Jeffery are equivalent to that of Smoluchowski within the useful range, they have not been duplicated here.

Uniformly distributed spheres:
Puisque les équations extrêmement compliquées de Faxén 22, Dahl 22 et Stimson et Jeffery 23 sont équivalentes à celles de Smoluchowski dans le domaine pratique, elles n'ont pas été reproduites ici.

Sphères uniformément réparties :

$$
\mathrm{K}=1+k \frac{d}{s}
$$

$$
\begin{array}{ll}
\text { Cunningham 1:: } & 1.7<k<2.25 \\
\text { Smoluchowski : } & k=1.16 \\
\text { Burgers } 25: & k=1.4 \\
\text { McNown et al } 15: & k=0.7
\end{array}
$$

VII. - ELIfPSOMDA PARTMCLE. VIT. - PARTCule ElLipsö̈DE.

McNown and Malaika:7:

$$
K=\frac{16}{3 d \zeta}
$$

in which:

dans lacpuelle:

$$
d=2 \sqrt{a b c}
$$

and for the eight possible cases:

et pour les huil cas possibles:

1. $a=b:=c: \zeta=\frac{8}{3 a}$

2. $a=b>c: \zeta=\frac{\left(3 a^{2}-2 c^{2}\right) \arccos (c / a)}{\left(a^{2}-c^{2}\right)^{2}{ }^{2}}-\frac{c}{t^{2}-c^{2}}$

3. $a=c<b: \zeta=\frac{\left(2 b^{2}-3 a^{2}\right) \operatorname{arccosh}(b / a)}{\left(b^{2}-a^{2}\right)^{3 / 2}}+\frac{b}{b^{2}-a^{2}}$

4. $a>b=c: \zeta=\frac{2\left(2 a^{2}-c^{2}\right) \operatorname{arc} c o s h(a / c)}{\left(t^{2}-c^{2}\right)^{3 / 2}}-\frac{2 a}{a^{2}-c^{2}}$

5. $a<b=c: \zeta=\frac{2\left(c^{2}-\frac{2}{2}\left(a^{2}\right) \arccos (a / c)\right.}{\left(c^{2}-a^{2}\right) \cdot 2}+\frac{2 a}{c^{2} \cdot a a^{2}}$

6. $a>b>c: \zeta=\frac{2\left[\left(2 a^{2}-b^{2}\right) F^{2}\left(\varphi_{1}, k_{1}\right)-a: \mathrm{E}\left(\varphi_{1}, k_{1}\right)\right]}{\left(a^{2}-b^{2}\right) \sqrt{a^{2}-c^{2}}}$,

$$
\begin{aligned}
& 9_{1}=\arccos \frac{c}{a}, \quad k_{1}=\sqrt{\frac{a^{2}-b^{2}}{a^{2}-c^{2}}} \\
& 9_{2}=\arccos (a / b), k_{2}=\sqrt{\frac{b^{2}-c^{2}}{b^{2}}}
\end{aligned}
$$

7. $b>c>a: \zeta=\frac{2 \mathrm{~F}\left(\varphi_{2}, k_{2}\right)}{\sqrt{b^{2}-a^{2}}}-\frac{2}{c^{2}-a^{2}}\left[\frac{a^{2} \mathrm{E}\left(0, k_{2}\right)}{\sqrt{b^{2}}}-\frac{a c}{b}\right]$,

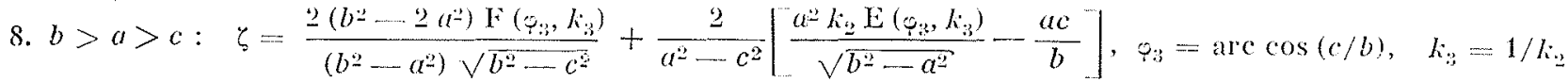


VIII. - Disk.

Elliptical disk:

\section{VIII. - Disque.}

Disc(ue elliptique :

$$
K^{\prime}=\frac{16}{3 d^{\prime} \zeta}
$$

Circular disk. -. Inertia effects:

Disque circulaire. -... Efrets d'inertie:

Oseen $4:$

$$
\mathrm{K}^{\prime}=\frac{8}{3 \pi}\left(1+\frac{2 R^{\prime}}{2 \pi}\right) \quad \quad R^{\prime}<0.1
$$

Effect of orientation:

Influence de l'orientation :

$$
\mathrm{K}_{\mathrm{Y}}^{\prime}=\frac{8}{3 \pi} \frac{4}{5+\cos 0}
$$

( $K^{\prime}{ }^{\prime}$ is the resistance coefficient for the vertical component of motion.)

( $\mathrm{K}_{\mathrm{V}}^{\prime}$ est le coefficient de résistance pour la composante vericale du mouvement.)

Horizontal movement:

Mouvement horizontal :

$$
\frac{V_{I I}}{V_{V}}=\frac{\sin 2 \varphi}{5+\cos 2 \varphi}
$$

IX. --.- Two Dimenstonat Mothon.

Circular cylinder:

Lamb 30 :

$$
\frac{F / l}{4 \pi ! V}=\frac{1}{2.00-\log _{e}(R}
$$

Elliptical cylinder:

Cylindre elliptique:

Bairstow :

$$
\frac{F / l}{4 \pi \because V}=\frac{1}{\frac{a}{a+b}+1.50-\log \frac{V(a+b)}{v}}
$$

X. Fifuid spheres.

X. - Siphères flumes.

Rybezinski $: 5$, Hadamard $3 t:$

$$
\mathrm{K}=\frac{2 \mu+3 \mu^{\prime}}{3 \xi+3 \mu^{\prime}}
$$

Surface viscosily:

Viscosité superficielle :

Boussinesc

$$
K=\frac{2 \varepsilon+\left(2 u+3 u^{\prime}\right) d}{2 \varepsilon+\left(3 \mu+3 \mu^{\prime}\right) d}
$$

\section{BIBLIOGRAPHY - BIBLIOGRAPHIE}

1. Sromes. - On the theories of the internal friction of fluids in motion, and of the equilibrium and motion of alastic solids. Camb. Trans., VIII, p. 287 (1845).

2. STokes. - On the effect of the internal friction of fluids on the motion of pendulum.

Camb. Trans., Ix, p. 8 (1851).
3. Snonuchowski. - On the practical applicability of Stokes's law of resistance and the modifications of it required in certain cases.

Proc. 5th Inter. Cong. of Math., Vol. II, Cambrige (1912).

4. Osres. - Hydrodynamik.

Akadem Verlags, Leipzig (1927). 
5. Weyssenhom. - Betrachtungen über den Guiltigkeitsbereich der Stokessehen und der Stokes-Cunninghamschen Formel.

Annalen der Physik, 4 Folge, $6 Z$, p. 1 (1920).

6. Schutar. - Fallversuche mit Kugeln und Scheiben. Handbach der Experimentalphysil, vol. IV, 2, p. 339, Leiprig (1932).

7. LAmB. - Hydrodynamics.

Cambridge, p. 562 (1932).

8. Golostein. - The steady flow of viscous fluid past a fixed spherical obstacle at small Reynolds numbers.

Proc. Roy. Soc. of London, A 123, p. 225 (1929).

9. Rouse. - Engineering Hydraulies.

Wiley, p. 115, New York (1949).

10. Arres. - The motion of a sphere in a viscous fluid.

Phil. Mag. and Jour, of Scien., 5 vol., 50, p. 323 (1900).

11. ArNold, - Limitations imposed by slip and inertia terms upon Stokes law for the motion of spheres through liquids.

Phil. Mag., vol. 22, p. 755 (1911).

12. Lamenbura. - Ueber den Einfluss von Wänden aut die Bewegung einer Kugel in einer reibenden Flüssigkeit.

Ann. d. Phys., vol. 23, p. 447 (1907).

13. Cunningham, - On the velocity of steady fall of spherical particles through fluid medium.

Proc. Roy. Soc. of London, A, vol. 83, p. 357 (1910).

14. Mernington. - Viscometry.

Arnold Co., London, chap. IV (1949).

15. McNown, LEe, MaPherson, FNGEz. - Influence of boundary proximity on the drag of spheres.

Proceedings VII Intern. Cong. App. Mech., London (1948)

16. Lonertz. - Ein allgemeiner Satz die Bewegung eine! reibenden Flissigkeit betreffend, nebst einigen Anwendungen desselben.

Zittingsverlag Alad, v. Wet, 5, Amsterdam (1896).; Abhand. ilber theoret. Physik, vol. I, Leipzig (1907).

17. Faxex. - Einwirkung der Gefässwände auf den Widerstand gegen die Bewegung einer kleinen Truget in einer zähen Flüssigkeit.

Diss. Upsala (1921).

18. Faxen. - Der Widerstand gegen die Bewegung einer starren Kugel in einer Flüssigkeit, die zwischen zwei parallelen ebenen Wänden cingeschlossen ist.

Arkib. för Mat. Astr. och Fysik, Bd 19 A (1925).

19. Altricher und Lustig. - Experimentelle Untersuchung über den Einfluss des Gefïssbodens aut die Fallbewegung von Kugeln in zähen Flüssigkeiten.

Phys. Zeits., 38, p. $786(1937)$.

20. Sunry. - Expériences sur le transport des courants d'eau et des courants d'air.

Annales de l'Inst. Océanographique, tome IV, fasc. IV (1912).

21. GHarr. - Matieres en suspension dans les caux des lleuves et sphères dans les liquides.

Gauthier-Villars, Paris (1935).

22. Faxen. - Gegenseitige Einwirkung zweicl Kugeln die in einer zähen Flüssigkeit fallen.

Nit cinem Nachtrag von H. Dahl, Alkil. för Mat. Astr. och Fysik, Bd., 19 A (1925).

23. STmson and Jeffery. - The motion of two spheres in a viscous fluid.

Proc. of the Royal Soc. of London, Ser. A, vol. III (1926).
24. Bandu. - Mutual influence of two frecly fallings spherical particles and the effects of a plane vertical boundary on a single spherical particle.

Thesis, University of Iowa, Iowa City (1950).

25. Bungers. - On the influence of the concentration of a suspension upon the sedimentation velocity (in particular for a suspension of spherical particles).

Proc. Acad. de Sci., v. 45, p. 126, Amsterdam (1942).

26. OnEnBEck. - Ueber stationäre Flüssigkeitsbewegungen mit Berücksichtigung der inneren Reibung.

Crelles Journal 81, p. 62 (1875).

27. McNown and Mararka. - Effects of particle shape on settling velocity at low Reynolds numbers.

Trans. of Am. Geophys. Union, vol. 31, p. 74 (1950).

28. Gavs. - Wie fallen Stäbe und Scheiben in einer reibenden Flüssigkeit.

Silzb. Alabb. Munich, p. 191 (1911).

29. Schmeder. - Experimentelle Untersuchungen übor die Fallbewegung von liugeln und Scheiben in reibenden Flüssigkeiten.

Phys. Zeits., 29, p. 593 (1928).

30. LAMB. - On the uniform motion of a sphere througl a viscous fluid.

Phil. Mag., 21, p. 112 (1911).

31. Barrstow, Gave, Lang. - The resistance of a cylinder moving in a viscous fluid.

Phil. Trans. Royal Soc. Landon, Serie A, vol. 223 (1923).

32. Barrsow, - The two dimensional slow motion of viscous fluids.

Proce Roly. Soc., vol, 100 , p. 394 (1922).

33. Vhrte. - The drag of cylinders in fluids at low speeds.

Proc. Roll. Soc, vol. 186, p. $472(1946)$.

34. Duraxp. -. Différentes deffinitions techniques de la forme des galets.

Comm. Société Hydrotech, de France, 1950.

35. Ryвczisski. --.- Ueber die fortschreitende Bewegung ciner flüssigen Kugel in einem zähen Medium.

Bull. Acad. des Sciences Cracovie, p. 40 (1911).

36. Hadamaro. - Mouvement permanent lent d'une sphère liquide et visqueuse dans un liquide visqueux.

Comples rendus Acad. Sciences, vol. 152, p. 1735, Paris (1911).

37. Bond. - Bubbles and drops and Stokes Law.

Phil. Mag. and Jour, of Sciences, 7, vol. 4, p. 889-898 (1927).

38. Rosenibri. - The drag and shape of aip bubbles moving in licguids.

Navy depl., rep. 727, Washington (1950).

39. Boussriveso. - Vitesse de la chute lente devenue uniforme d'une goutte liquide sphérique dans un fluide visqueux de poids spécifique moindre.

Comptes rendus de l'Acad. des Sciences, 156, p. 1.124. Paris (1913).

40. Duchaux. - Viscosité.

Hermann et Cie, p. 18, Paris (1934).

4. Frenkel. - Kinetic theory of liguids.

At the Clarendon Press (1946).

42. Bond and Newron. - Bubbles, drops and Stokes Law.

Phil. Mag., 7, vol. 5, p. 794-800 (1928).

43. Sinver. - - The fall of mercury droplets in a viscous medium.

The Physical Review, VII, 2, p. 106-11 (1916). 